\title{
10
}

\section{FEMALE LABOUR FORCE PARTICIPATION IN INDONESIA: WHY HAS IT STALLED?}

Lisa Cameron, Diana Contreras Suarez and William Rowell

\section{Introduction}

Indonesia now boasts the largest economy in the Association of Southeast Asian Nations (ASEAN) and the 16th worldwide (Asian Development Bank (ADB) 2015). The economy has expanded considerably since the 1970s, except when growth halted temporarily during the East Asian financial crisis of 1997-98. Continued economic development has meant rising average incomes, changes in the sectoral structure of the economy (from agriculture to manufacturing and services) and increasing industrialisation and urbanisation, among other changes (Elias \& Noone 2011). Despite the significant changes in the Indonesian economy, the impact on the experience of women in the labour market is muted. The 2014 World Development Indicators show that 51.4 per cent of Indonesian women aged 15 and above participate in the labour force (either working or looking for work). This participation rate has remained largely unchanged over the past two decades and the large gap between female and male labour force participation persists. Female labour force 
participation in Indonesia remains low relative to countries in the region at a comparable stage of development (see also ADB, International Labour Organization (ILO) \& Islamic Development Bank (IDB) 2010).

The aim of this paper is to identify the drivers of female labour force participation (FLFP) in Indonesia and why FLFP has remained unchanged over the period 1996 to 2013. We separate labour force participation into components on the supply and demand sides of the labour market - educational attainment, marital status, fertility, household structure, distance to urban centres, main local industries - and implement a cohort analysis that separates out the effect of life cycle factors (age) on women's labour force participation and cohort effects (changes in participation over time).

Understanding the constraints that women face in the labour market is essential in forming policies aimed at addressing these constraints to encourage FLFP. Previous studies attribute the gender gap in participation to family roles, child-caring and cultural norms in relation to women's traditional roles (Jayachandran 2015). Increases in participation are likely to have flow-on effects through female empowerment that, in turn, may affect other facets of the gender divide - for example, political representation, having greater say over household decision-making and being less accepting of spousal violence. Identifying the drivers of low FLFP is also important to help address constraints facing the Indonesian economy, which is trying to shift from a pattern of economic growth driven by resources and cheap labour and capital to growth based on high productivity and innovation (ADB 2015). Increased FLFP has the potential to be a key contributor to improving Indonesia's productivity, enabling it to avoid the middle-income trap and continue its economic development into the future.

Although the raw figures on women's labour market participation show little change over the last two decades, we show that this masks changes that offset one another in the current population. The analysis produces several key results. First, the main drivers of FLFP appear to be on the supply side - marital status, educational attainment and the number of children aged between 0 and 2 years of age present in the household. On the demand side, the main source of village income (reflecting the local industrial structure) impacts FLFP. 
Second, we find higher education is important to increase FLFP at young ages when household responsibilities are the main barrier to women participating. Most single and highly educated women have entered the labour market by age 25 and keep participating almost until retirement age. In contrast, women who are married, less educated and have children only increase their participation rates after age 40 .

Third, once we control for individual and household characteristics, we find that the underlying propensity for FLFP has increased over time, despite the lack of change in the aggregate figures. The cohort analysis shows that labour force participation of young females is higher than their older counterparts with similar characteristics at the same age. This is particularly marked in urban areas. If this trend continues, we expect the aggregate level of FLFP to increase over time as the older cohorts exit the labour market - although the changing composition of the economy away from the agriculture sector currently works in the opposite direction.

Even with this increase in younger women's labour market participation, the projections from our model show that, without considerable policy support, it is unlikely that Indonesia will reach its G20 commitment of reducing the gap between male and female labour force participation by 25 per cent by $2025 .^{1}$ This implies an increase in FLFP from 51.4 per cent to 58.5 per cent.

Our findings suggest that policy interventions should be aimed predominantly at the supply side. For example, policies aimed at improving access to tertiary education for girls, particularly in rural areas where education levels remain low, would be likely to increase FLFP.

Barriers related to the traditional view of women's role in the household and reflecting expectations that a woman leaves the labour force once she is married or has had children, may be more difficult to overcome. But our results suggest that shifts are occurring in these cultural norms, particularly in urban areas. Policies supporting married women to re-enter the labour market, especially in urban areas, such as through the provision of child care, would improve the likelihood of FLFP increasing in the future. Strategies that support women working while looking after the family, such as the provision of part-time, family-friendly work, are also likely to help.

1 Figure 10.A.1 shows G20 FLFP goals for all G20 countries, and the base G20 FLFP measure (defined as labour force participation in 2012). 
The next section discusses the relevant literature on FLFP in Indonesia and beyond. This is followed by sections that present the data used and the empirical strategy. We then discuss the findings and use our estimated model to project Indonesia's FLFP into the future. The final section concludes and discusses policy implications.

\section{Literature review}

Unchanged and low FLFP despite rapid growth, fertility decline and increased female educational attainment is not a phenomenon unique to Indonesia. Figure 10.1 shows the level of FLFP in the ASEAN +3 countries (ASEAN plus China, Japan and South Korea) and how it changed between 1995 and 2017. Indonesia is among the countries with the lowest level of FLFP and sits in a similar range to Malaysia, Myanmar, the Philippines, Korea and Japan. India has also experienced rapid economic growth and its FLFP has remained low at 18 per cent. Klasen and Pieters (2015) find that the stagnation of FLFP in urban India since the 1980s is largely due to an increase in male education and income, a change in the sectoral structure of the economy where the share of employment in agriculture and manufacturing has decreased (these are the sectors that tend to employ more unskilled women), and a decline over time of the positive effect of secondary and tertiary education. Further, Afridi et al. (2016) and Andres et al. (2017) study the decline in FLFP in India, including rural areas. Using different methodological approaches, both find that increasing education levels for married women and men in their household as well as stability in family income are the major contributors to the decline. Countries in the Middle East and North Africa also have low and constant levels of FLFP despite increases in female education levels. Gaddis and Klasen (2014) suggest that this pattern can be partially explained by conservative social attitudes towards women's work. In contrast, Latin-American countries experienced rapid economic growth during the second half of last century accompanied by significant growth in FLFP. The increase in FLFP has been attributed to women's increased education levels and reductions in fertility rates (Gasparini et al. 2015). Changes in the sectoral structure of the economy minimally affected women's participation. There has, however, been a de-acceleration of FLFP growth in Latin America in the last two decades. 


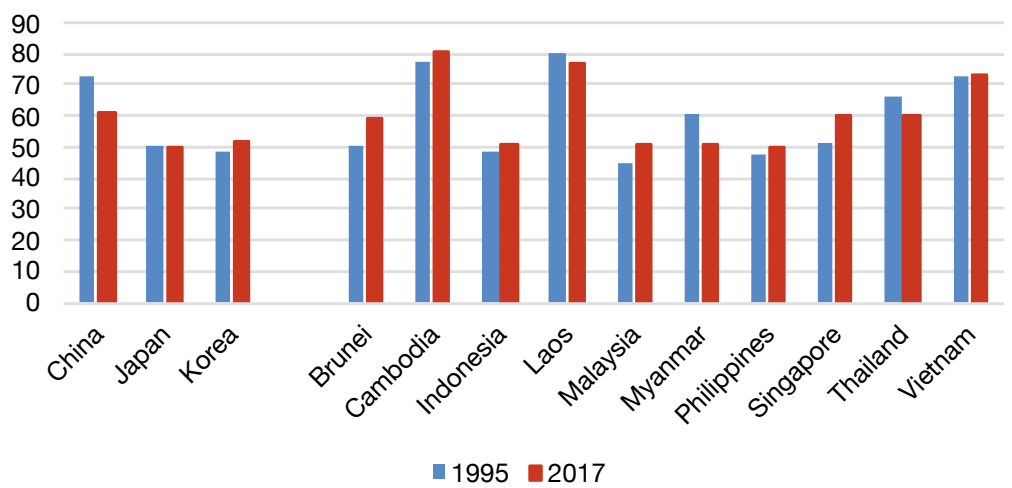

Figure 10.1. ASEAN+3 FLFP, 1995-2017

Source. World Bank 2017, modelled ILO estimates available at: data.worldbank.org/ indicator/SL.TLF.CACT.FE.ZS

The empirical literature that focuses on the drivers of FLFP in Indonesia is relatively sparse. Schaner and Das (2016) use 21 years of the Indonesian National Labour Force Survey (SAKERNAS) to identify the barriers to and drivers of FLFP. They focus on trends by birth cohort, educational attainment, geography and the type of work (e.g. informal sector, selfemployed, employee). They also use the 2012 Indonesia Demographic and Health Survey to examine the correlations between female labour market outcomes and proxies of empowerment, household wealth and family structure including fertility. Their main findings are that younger women in urban areas have increased their labour force participation in recent years and this has largely been achieved by wage employment. Younger women in rural areas, however, have reduced their labour force participation largely by opting out of informal/unpaid employment. They also find evidence of within-country U-shaped relationships between FLFP and education and wealth, suggesting that one reason why FLFP has remained constant despite large gains in income and educational attainment is that the growth in FLFP at the top of the income and education distribution has largely been offset by losses at the bottom of the distribution. Child care responsibilities are another factor that limits women's engagement in the labour market. Women with young children are significantly less likely to work relative to their childless peers. Women appear to re-enter the labour force as their children get older either by performing family work or being self-employed but there is no re-entry into wage employment as children age. Finally, they find that wage jobs are preferred among women, but they are predominantly held by highly educated women in urban areas. 
Feridhanusetyawan and Aswichayono (2001) use SAKERNAS data to examine the changing patterns of male and FLFP and earnings in Indonesia from 1986 to 1997 . Their main finding is that, with time, women stayed in the labour market longer over this period. They find an inverse U-shaped relationship between labour force participation and age. While at the beginning of the period the participation turning point for women was earlier than for men, by the end of the 1990s the peakages for males and females were similar. Education played a significant role in determining labour force participation especially in urban areas, and the effects were stronger for females than males early in the period. But, by the late 1990s, the effects were similar for males and females. They found that the probability of a woman entering the labour market declines significantly if she is married or has more dependent children in the family. But for men, being married and having more dependent children increases the probability of entering the labour market.

Comola and de Mello (2009) examined the determinants of employment and earnings for the Indonesian labour market. They use a multinomial logit model to estimate labour market status (e.g. unemployed, employed in the formal sector, or employed in the informal sector) on SAKERNAS data for 1996 and 2004. Their focus is not explicitly on gender but they find that women living in a household with a high dependency ratio are less likely to have a formal-sector job and more likely to be inactive than those in a low dependency household. Women's labour force participation declines during their most fertile years. Van Klaveren et al. (2010) show that, while male labour market participation is highest in the age range of 35-49 years, for females it is highest in the post-child-rearing years (ages 45-59).

Cepeda (2013), in an analysis for the World Bank, uses information from the 2009 SAKERNAS to show that single women aged 15 to 24 have the highest rate of participation compared to other marital categories in this age range. The aggregate drop in participation on marriage in this age range is an enormous 37.7 percentage points. Interestingly the biggest drop is among married women without children and, after the first child, the reduction decreases per each additional child. One of the suggested explanations for this is an anticipatory effect. As women get married they expect to have children immediately, so they stop working even before pregnancy. From age 25 to 64, divorced and widowed women with children are the ones with the highest labour force participation. 
Alisjahbana and Manning (2006) show that women's labour force participation decisions reflect a combination of marital and socioeconomic status. Poorer married women are more likely to participate than married women in non-poor households.

\section{Data}

The data used in this paper come from two sources - the National Socioeconomic Survey (SUSENAS) and the Village Potential Statistics (PODES).

The SUSENAS is a nationally representative survey conducted annually and typically covering about 200,000 households. Each survey contains a core questionnaire that consists of a household roster listing the sex, age, marital status, and educational attainment of all household members. ${ }^{2}$ It also includes questions on labour market activity, health, fertility, and other household characteristics.

One of the advantages of the SUSENAS data set (over the more widely used SAKERNAS) is that it collects information on household composition, which allows us to explore the role of child-raising and the availability of alternative child-carers in the household (primarily grandparents and other women who could act as babysitters) in the decision to participate. We supplement the SUSENAS data with data from the PODES, which is a three-yearly census of all villages across Indonesia (approximately 65,000). We use the PODES for information on some demand-side characteristics of the labour market, such as the distance to the nearest district office (to act as a proxy for access to jobs) and the main source of income of the village. ${ }^{3}$

2 This core questionnaire is supplemented by modules covering about 60,000 households that collect additional information, such as health care and nutrition, household income and expenditure, and labour force experience.

3 We extract the distance to the nearest district office from the 2011 PODES. The main source of village income is likely to change over time due to the changing composition of the Indonesian economy, so for this PODES variable we merge the PODES data to the closest year of the SUSENAS data. For 1996, 2000 and 2011 we match the PODES with the corresponding year of the SUSENAS. For the 2007 SUSENAS, we merge with the 2008 PODES because there is no PODES for that particular year. In 2013, we use the information from the 2011 PODES as this is the closest year. However, the 2013 SUSENAS does not include the unique village identifiers that are available in other years. District is the smallest geographical unit reported so we calculate the main income source at the district level using PODES 2011 and merge it with the 2013 SUSENAS data. As a robustness check, we re-estimated our main results excluding the 2013 data. The results were similar, so the 2013 data was retained for the estimation. 
The available data allow us to control for the following characteristics that could impact on FLFP,

- at the individual level, we control for whether the individual is the head of the household, marital status (e.g. married, divorced, widowed or single), and the level of education completed by the individual (e.g. primary school, lower secondary school, upper secondary school, or tertiary education)

- at the household level, we control for the number of people living in the household, the number of females aged between 45 and 65 years in the household (excluding the female respondent) who are potential babysitters, the number of elderly (defined as greater than or equal to 65 years of age) women and men in the household and the number of children in the household by age (the age groupings are $0-2$ years of age, 3-6, 7-11, and 12-17)

- at the village level, we control for distance to the nearest district office and the main source of village income. We also control for provincial unemployment rates (calculated from the SUSENAS) to act as a proxy for the underlying economic conditions at that time.

A disadvantage of the SUSENAS is that it is cross-sectional, so we cannot observe the same individuals or households across time (this is true also of the SAKERNAS). But, by using the SUSENAS from 1996, 2000, 2007, 2011 and 2013 survey years, we can observe how the participation of different birth cohorts (groups of people born in the same years) change over time and life cycle (age) effects.

\section{Methodology}

To estimate the determinants of FLFP we regress whether an individual participates in the labour force or not $\left(y_{i}=1 / 0\right)$ on a set of potential drivers $\left(x_{i}\right)$ using a probit model. That is, we estimate:

$$
y_{i}=\beta_{0}+\sum_{j=1}^{k} \beta_{j} x_{j i}+\varepsilon_{i}
$$

The vector of potential drivers $\left(x_{i}\right)$ includes those discussed above. On the supply side of the labour market we control for marital status, if the individual is the head of the household, the highest level of education achieved, household size, the presence of a babysitter or elderly men or 
women in the household and the number of children at certain ages. On the demand side, we include distance to the nearest district office and the main source of income in the village. We also control for geographic differences using province dummies and the unemployment rate for each province.

Intuitively, the regression identifies the relationship between the control variable and labour force participation. The magnitude of the effect is captured by the coefficient on the control variable $\left(\beta_{\mathrm{j}}\right)$.

Dummy variables are also included for the age of the individual at the time of the survey and their year of birth. The coefficients (and associated marginal effects) on the age dummies capture how an individual's likelihood of participating varies across the life cycle, irrespective of their year of birth and after controlling for other characteristics. The coefficients on the year of birth dummy variables allow us to compare people born in different years, which identifies whether the younger cohorts behave differently in relation to labour force participation than their older counterparts and the extent to which the propensity to participate in the labour market has changed over time. ${ }^{4}$

We estimate equation (1) separately for men and women and disaggregate by rural and urban status. ${ }^{5}$

\section{Results}

\section{Descriptive results}

Table 10.1 presents the summary statistics of labour force participation and the explanatory variables for urban and rural areas. At the individual level, there is a substantial gap between female and male labour force participation - FLFP is on average 33 percentage points (approximately 40 per cent) less than male participation (85 per cent compared to 52 per cent). The participation rates also tend to be higher in rural areas

4 We use 49 age dummies covering from 15 to 64 years of age (the omitted category is 15 years of age) and 49 cohort dummies - one for each year of birth from 1943 to 1992 (the omitted category is someone born in 1943). See Euwals et al. (2011) for a similar approach in the context of the Netherlands.

5 Separately estimated results for Java-Bali and the outer islands are presented in the appendix. 
compared to urban areas for both men and women. Most household heads are males, and most females and males are married. At the household level, there are more potential babysitters in households in urban areas, possibly due to higher housing prices. At the village level, the distances to the nearest district office (a proxy for the distance to the labour market) are unsurprisingly less in urban areas. Agriculture is most prevalent in rural areas compared to urban areas where services and large trade/retail represent income sources.

Table 10.2 disaggregates the summary statistics by survey year. The key results are that the gender gap in labour force participation remains largely unchanged over the period (see also Figure 10.2). Educational attainment has increased over time, with women's educational attainment increasing more than men's. Household size has shrunk over time, and the average number of children per household has declined. Finally, the unemployment rate shows a downward trend from 1996 to 2013.

Table 10.1. Summary statistics of labour force participation and explanatory variables

\begin{tabular}{|c|c|c|c|c|}
\hline \multirow[b]{2}{*}{ Variables } & \multicolumn{2}{|c|}{ Urban } & \multicolumn{2}{|c|}{ Rural } \\
\hline & Male & Female & Male & Female \\
\hline \multicolumn{5}{|l|}{ Individual characteristics: } \\
\hline Labour force participation & 0.813 & 0.475 & 0.886 & 0.565 \\
\hline Household head & 0.573 & 0.075 & 0.621 & 0.067 \\
\hline Marital status: single & 0.371 & 0.288 & 0.308 & 0.199 \\
\hline Marital status: married & 0.611 & 0.634 & 0.670 & 0.718 \\
\hline Marital status: divorced & 0.009 & 0.026 & 0.010 & 0.026 \\
\hline Marital status: widowed & 0.009 & 0.052 & 0.012 & 0.057 \\
\hline Education: primary & 0.213 & 0.237 & 0.368 & 0.364 \\
\hline Education: lower secondary & 0.231 & 0.227 & 0.199 & 0.170 \\
\hline Education: upper secondary & 0.360 & 0.301 & 0.159 & 0.113 \\
\hline Education: tertiary & 0.105 & 0.095 & 0.028 & 0.025 \\
\hline \multicolumn{5}{|l|}{ Household characteristics: } \\
\hline Household size & & 4.810 & & 4.697 \\
\hline Number of women aged $45-65$ years & & 0.313 & & 0.276 \\
\hline Number of elderly females & & 0.077 & & 0.076 \\
\hline Number of elderly males & & 0.065 & & 0.071 \\
\hline Number of children: 0-2 years & & 0.223 & & 0.247 \\
\hline
\end{tabular}


10. FEMALE LABOUR FORCE PARTICIPATION IN INDONESIA

\begin{tabular}{|c|c|c|c|c|}
\hline \multirow[b]{2}{*}{ Variables } & \multicolumn{2}{|c|}{ Urban } & \multicolumn{2}{|c|}{ Rural } \\
\hline & Male & Female & Male & Female \\
\hline Number of children: 3-6 years & & 0.309 & & 0.364 \\
\hline Number of children: $7-11$ years & & 0.423 & & 0.507 \\
\hline Number of children: $12-17$ years & & 0.663 & & 0.6750 \\
\hline \multicolumn{5}{|l|}{ Village characteristics: } \\
\hline Distance to nearest district office $(<100 \mathrm{~km})$ & & 0.462 & & 0.788 \\
\hline Main income: agriculture & & 0.309 & & 0.961 \\
\hline Main income: mining/quarrying & & 0.011 & & 0.004 \\
\hline Main income: processing/industry & & 0.087 & & 0.008 \\
\hline Main income: large trading/retail & & 0.243 & & 0.009 \\
\hline Main income: services other than trade & & 0.350 & & 0.018 \\
\hline Unemployment ${ }^{\#}$ & & 0.039 & & 0.033 \\
\hline Observations & 469,157 & 481,751 & 681,427 & 691,280 \\
\hline
\end{tabular}

Notes. "Unemployment rate by region.

Source. Authors' calculations using SUSENAS and PODES

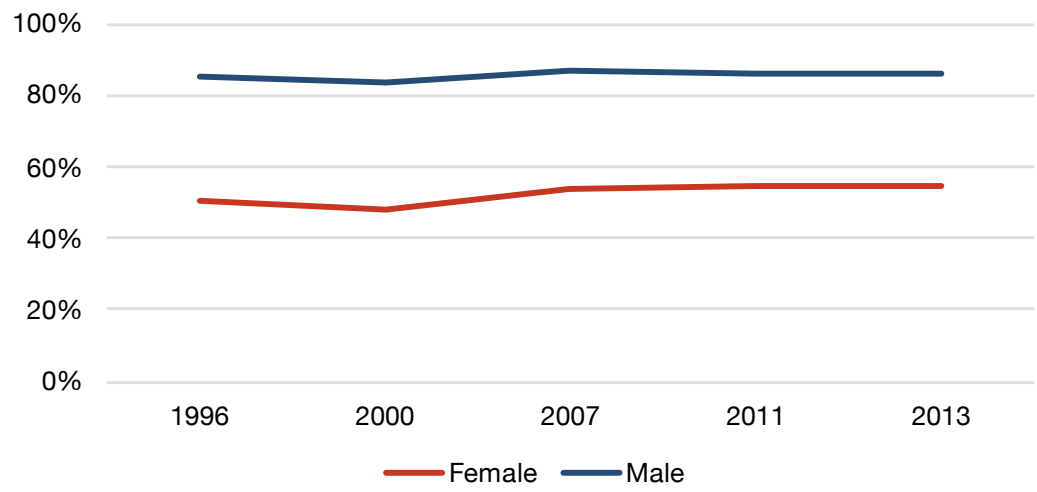

Figure 10.2. Female and male labour force participation over time

Source. Authors' calculations using SUSENAS 


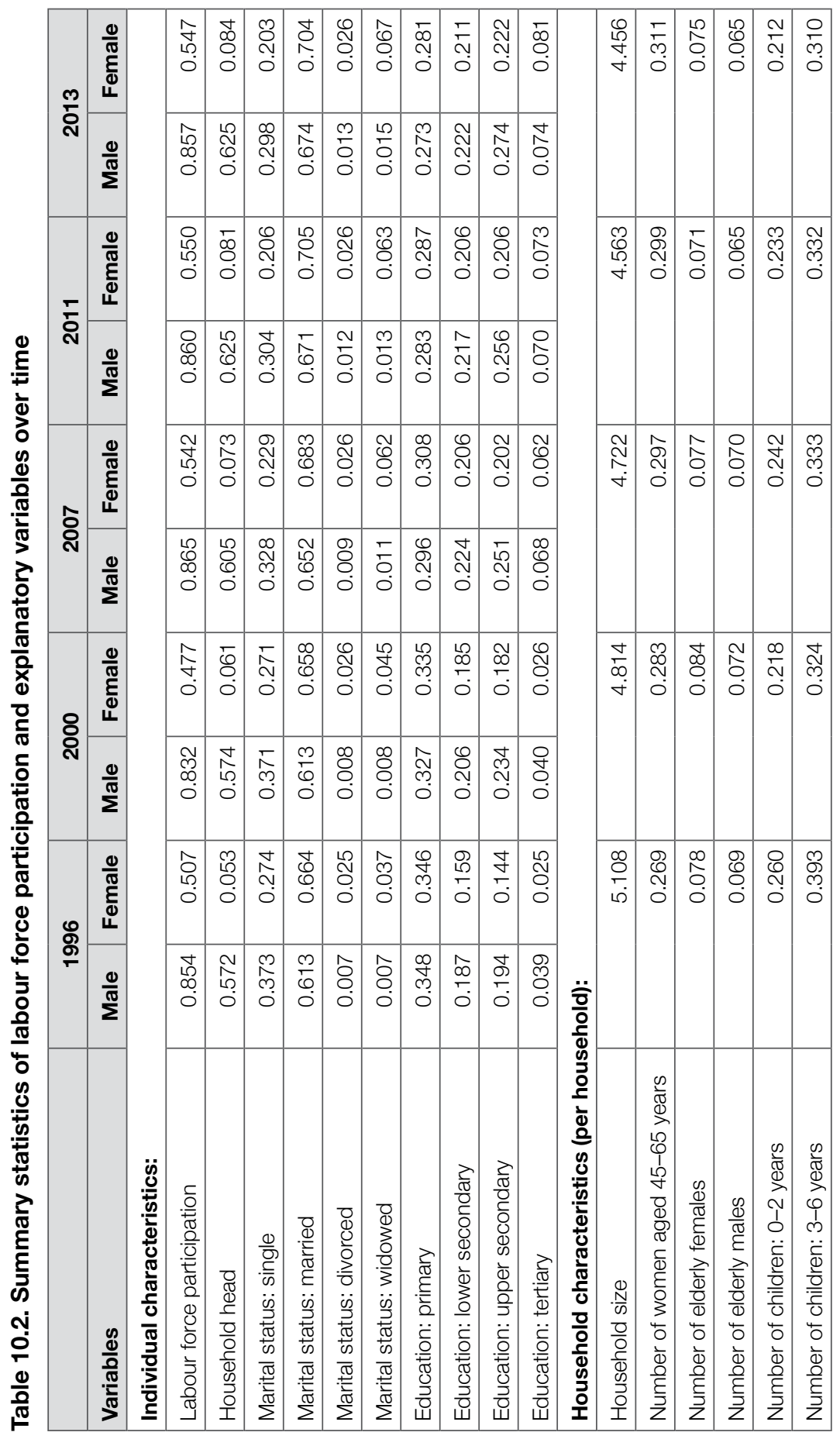


10. FEMALE LABOUR FORCE PARTICIPATION IN INDONESIA

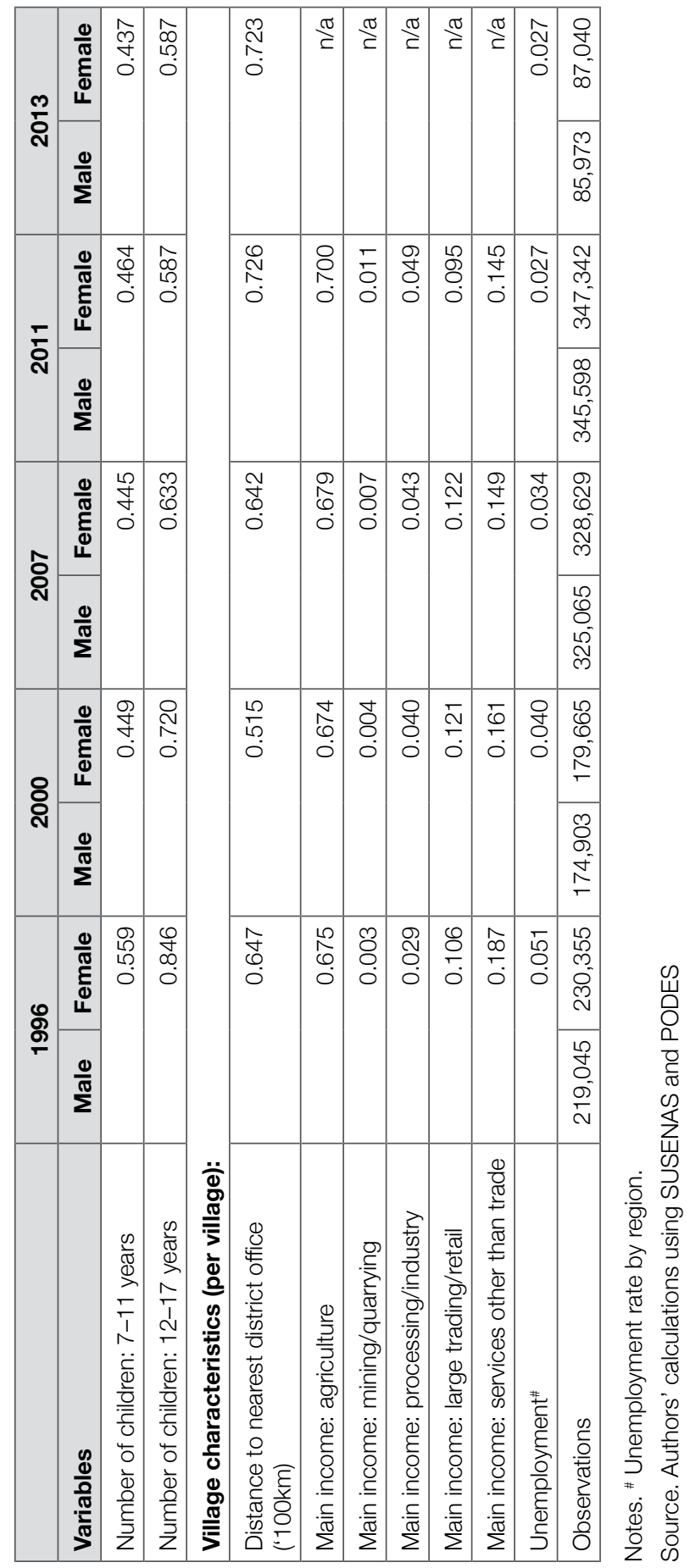


Looking at age differences, Table 10.3 shows that labour force participation is lowest in the 15-29 age group. This is likely due to these individuals still being in school or completing higher levels of education. The proportion of those who are household heads follows a similar trend. Nearly half of all women aged 15 to 29 years are married and this increases to around 90 per cent for those aged 30 to 44 years. This decreases to 75 per cent for women aged 45 to 64 years as the proportion of widowers increases by a commensurate amount. Lastly, in terms of educational attainment, while there is a clear gender gap in attainment for the older age groups, there is no gender gap between males and females in the youngest cohorts. There is a greater share of females completing tertiary education than males.

Table 10.3. Summary statistics of labour force participation and individual characteristics by age group

\begin{tabular}{|l|r|r|r|r|r|r|}
\hline & \multicolumn{3}{|c|}{ Male } & \multicolumn{3}{c|}{ Female } \\
\hline Variables & $\mathbf{1 5 - 2 9}$ & $\mathbf{3 0 - 4 4}$ & $\mathbf{4 5 - 6 4}$ & $\mathbf{1 5 - 2 9}$ & $\mathbf{3 0 - 4 4}$ & $\mathbf{4 5 - 6 4}$ \\
\hline Labour force participation & 0.700 & 0.980 & 0.938 & 0.422 & 0.596 & 0.610 \\
\hline Household head & 0.185 & 0.841 & 0.960 & 0.020 & 0.056 & 0.183 \\
\hline Marital status: single & 0.741 & 0.077 & 0.016 & 0.519 & 0.048 & 0.022 \\
\hline Marital status: married & 0.253 & 0.903 & 0.939 & 0.463 & 0.892 & 0.753 \\
\hline Marital status: divorced & 0.005 & 0.013 & 0.012 & 0.015 & 0.031 & 0.037 \\
\hline Marital status: widowed & 0.001 & 0.007 & 0.033 & 0.003 & 0.029 & 0.188 \\
\hline Education: primary & 0.295 & 0.306 & 0.320 & 0.304 & 0.334 & 0.292 \\
\hline $\begin{array}{l}\text { Education: lower } \\
\text { secondary }\end{array}$ & 0.302 & 0.169 & 0.120 & 0.293 & 0.147 & 0.089 \\
\hline $\begin{array}{l}\text { Education: upper } \\
\text { secondary }\end{array}$ & 0.263 & 0.267 & 0.163 & 0.243 & 0.196 & 0.088 \\
\hline Education: tertiary & 0.035 & 0.080 & 0.069 & 0.049 & 0.068 & 0.040 \\
\hline Observations & 469,998 & 406,980 & 273,606 & 482,448 & 418,598 & 271,985 \\
\hline
\end{tabular}

Source. Authors' calculations using SUSENAS

\section{Estimation results}

Table 10.4 presents the results of estimating equation (1) for men and women by rural and urban status. For ease of interpretation we present marginal effects, which are interpreted as the percentage point change in the probability of the individual participating in the labour market associated with a one unit change in that explanatory variable. Marital status is a key driver of labour force participation for women. A married woman in a 
rural area is 11 percentage points less likely to be working or looking for work than a single woman and this difference is statistically significant. The impact is more pronounced for married women in urban areas as they are 24 percentage points less likely to be participating than single women.

\section{Table 10.4. Marginal effects of pooled sample}

\begin{tabular}{|c|c|c|c|c|}
\hline \multirow[t]{2}{*}{ Variables } & \multicolumn{2}{|c|}{ Rural } & \multicolumn{2}{|c|}{ Urban } \\
\hline & Female & Male & Female & Male \\
\hline \multirow[t]{2}{*}{ Household head } & $0.2109^{\star \star *}$ & $0.0565^{\star \star \star}$ & $0.1143^{\star \star \star}$ & $0.0370^{\star \star \star}$ \\
\hline & $(0.0031)$ & $(0.0015)$ & $(0.0040)$ & $(0.0021)$ \\
\hline \multicolumn{5}{|l|}{ Marital status: single (omitted) } \\
\hline \multirow[t]{2}{*}{ Marital status: married } & $-0.1068^{\star \star \star}$ & $0.0753^{\star \star \star}$ & $-0.2430^{\star \star \star}$ & $0.1589^{\star \star \star}$ \\
\hline & $(0.0025)$ & $(0.0016)$ & $(0.0028)$ & $(0.0025)$ \\
\hline \multirow[t]{2}{*}{ Marital status: divorced } & $0.0101^{\star \star}$ & $0.0088^{\star \star \star}$ & $0.0156^{\star \star \star}$ & $0.0300^{\star \star \star}$ \\
\hline & $(0.0050)$ & $(0.0019)$ & $(0.0058)$ & $(0.0034)$ \\
\hline \multirow[t]{2}{*}{ Marital status: widowed } & $-0.1585^{\star \star \star}$ & $0.0145^{\star \star \star}$ & $-0.1525^{\star \star \star}$ & $0.0493^{\star \star \star}$ \\
\hline & $(0.0046)$ & $(0.0016)$ & $(0.0048)$ & $(0.0025)$ \\
\hline \multicolumn{5}{|l|}{ Education: no schooling (omitted) } \\
\hline \multirow[t]{2}{*}{ Education: primary } & $-0.0303^{\star \star \star}$ & $0.0017^{\star \star}$ & $-0.0215^{\star \star \star}$ & $0.0160^{\star \star \star}$ \\
\hline & $(0.0016)$ & $(0.0007)$ & $(0.0026)$ & $(0.0018)$ \\
\hline \multirow[t]{2}{*}{ Education: lower secondary } & $-0.1101^{\star \star \star}$ & $-0.0453^{\star \star \star}$ & $-0.1008^{\star \star \star}$ & $-0.0558^{\star \star \star}$ \\
\hline & $(0.0021)$ & $(0.0011)$ & $(0.0027)$ & $(0.0023)$ \\
\hline \multirow[t]{2}{*}{ Education: upper secondary } & $-0.0313^{\star \star \star}$ & $-0.0309^{\star \star \star}$ & $-0.0162^{\star \star \star}$ & $-0.0382^{\star \star \star}$ \\
\hline & $(0.0024)$ & $(0.0012)$ & $(0.0026)$ & $(0.0020)$ \\
\hline \multirow[t]{2}{*}{ Education: tertiary } & $0.2745^{\star \star \star}$ & $-0.0095^{\star \star \star}$ & $0.2794^{\star \star \star}$ & $0.0066^{\star \star \star}$ \\
\hline & $(0.0032)$ & $(0.0022)$ & $(0.0030)$ & $(0.0023)$ \\
\hline \multirow[t]{2}{*}{ Household size } & $-0.0160^{\star \star \star}$ & $-0.0049^{\star \star \star}$ & $0.0048^{\star \star \star}$ & $-0.0040^{\star \star \star}$ \\
\hline & $(0.0006)$ & $(0.0002)$ & $(0.0006)$ & $(0.0004)$ \\
\hline \multirow{2}{*}{$\begin{array}{l}\text { Number of women aged } 45-65 \\
\text { years }\end{array}$} & $0.0173^{\star \star \star}$ & $0.0048^{\star \star \star}$ & $0.0121^{\star \star \star}$ & $-0.0059^{\star \star \star}$ \\
\hline & $(0.0020)$ & $(0.0005)$ & $(0.0022)$ & $(0.0011)$ \\
\hline \multirow[t]{2}{*}{ Number of elderly females } & $0.0316^{\star \star \star}$ & $0.0034^{\star \star \star}$ & $0.0099^{\star * \star}$ & $-0.0042^{* *}$ \\
\hline & $(0.0025)$ & $(0.0009)$ & $(0.0029)$ & $(0.0017)$ \\
\hline \multirow[t]{2}{*}{ Number of elderly males } & $0.0244^{\star \star \star}$ & $0.0088^{\star \star \star}$ & $0.0206^{\star \star \star}$ & $0.0065^{\star \star \star}$ \\
\hline & $(0.0024)$ & $(0.0009)$ & $(0.0030)$ & $(0.0019)$ \\
\hline \multirow[t]{2}{*}{ Number of children: 0-2 years } & $-0.0797^{\star * *}$ & $0.0104^{\star \star \star}$ & $-0.0754^{\star \star \star}$ & $0.0188^{\star * *}$ \\
\hline & $(0.0016)$ & $(0.0007)$ & $(0.0020)$ & $(0.0014)$ \\
\hline \multirow[t]{2}{*}{ Number of children: 3-6 years } & $0.0056^{\star \star *}$ & $0.0083^{\star \star \star}$ & $-0.0248^{\star \star \star}$ & $0.0172^{\star \star \star}$ \\
\hline & $(0.0013)$ & $(0.0005)$ & (0.0016) & $(0.0011)$ \\
\hline
\end{tabular}




\begin{tabular}{|c|c|c|c|c|}
\hline \multirow[t]{2}{*}{ Variables } & \multicolumn{2}{|c|}{ Rural } & \multicolumn{2}{|c|}{ Urban } \\
\hline & Female & Male & Female & Male \\
\hline \multirow[t]{2}{*}{ Number of children: $7-11$ years } & $0.0254^{\star \star \star}$ & $0.0087^{\star \star \star}$ & $-0.0043^{\star \star \star}$ & $0.0153^{\star * \star}$ \\
\hline & $(0.0012)$ & $(0.0004)$ & $(0.0014)$ & $(0.0009)$ \\
\hline \multirow[t]{2}{*}{ Number of children: $12-17$ years } & $0.0225^{\star \star \star}$ & $0.0073^{\star \star \star}$ & $0.0042^{\star \star *}$ & $0.0119^{* * *}$ \\
\hline & $(0.0011)$ & $(0.0004)$ & $(0.0012)$ & $(0.0007)$ \\
\hline \multirow[t]{2}{*}{ Distance to district office (' $100 \mathrm{~km})$} & $0.0016^{*}$ & 0.0002 & $0.0173^{\star \star \star}$ & $0.0065^{\star \star *}$ \\
\hline & $(0.0009)$ & $(0.0003)$ & $(0.0016)$ & (0.0009) \\
\hline \multicolumn{5}{|l|}{ Main income: agriculture (omitted) } \\
\hline \multirow[t]{2}{*}{ Main income: mining/quarrying } & $-0.1186^{\star \star \star}$ & -0.0048 & $-0.0743^{\star \star \star}$ & -0.0012 \\
\hline & $(0.0103)$ & $(0.0041)$ & $(0.0076)$ & (0.0051) \\
\hline \multirow[t]{2}{*}{ Main income: processing/industry } & $-0.0196^{\star \star \star}$ & -0.0039 & 0.0029 & 0.0007 \\
\hline & $(0.0071)$ & (0.0028) & $(0.0030)$ & $(0.0019)$ \\
\hline \multirow[t]{2}{*}{ Main income: large trading / retail } & $-0.0953^{\star \star \star}$ & $-0.0294^{\star * \star}$ & $-0.0218^{\star \star \star}$ & $-0.0185^{\star \star \star}$ \\
\hline & $(0.0069)$ & $(0.0034)$ & $(0.0021)$ & $(0.0014)$ \\
\hline \multirow{2}{*}{$\begin{array}{l}\text { Main income: services other than } \\
\text { trade }\end{array}$} & $-0.1328^{\star \star \star}$ & $-0.0328^{* * *}$ & $-0.0433^{\star \star \star}$ & $-0.0319^{\star \star \star}$ \\
\hline & $(0.0048)$ & (0.0025) & $(0.0020)$ & (0.0013) \\
\hline \multirow[t]{2}{*}{ Unemployment ${ }^{\#}$} & $-0.0083^{\star \star \star}$ & $0.0029^{\star \star \star}$ & $-0.0223^{\star * \star}$ & $-0.0053^{\star \star \star}$ \\
\hline & (0.0006) & (0.0002) & $(0.0007)$ & (0.0004) \\
\hline Observations & 691,280 & 681,427 & 481,751 & 469,157 \\
\hline
\end{tabular}

Notes. Standard errors in parentheses, ${ }^{* *} p<0.01,{ }^{* *} p<0.05,{ }^{*} p<0.1$. Estimations include province, age and date of birth fixed effects. \# Unemployment rate by region.

Source. Authors' calculations using SUSENAS and PODES

Being a household head for both men and women increases the likelihood of labour force participation in both urban and rural areas. But the magnitude of the impact for men is substantially smaller because men are generally the primary income earners, so largely work irrespective of whether they are the household head or not. The level of educational attainment is also a strong driver of FLFP. For women, completing upper secondary school increases the likelihood of participation compared to someone who only completed lower secondary by about 8 percentage points in both rural and urban areas. The magnitude of the impact increases dramatically if women attain the next education level (tertiary education). But for men, there is little variation in the probability of participating regardless of levels of education. Men, as the main breadwinners in Indonesian society, tend to work. 
Household size decreases participation for women in rural areas - an increase in household size by one decreases the likelihood of participation by nearly 2 percentage points. But the magnitude of the impact for urban females and males is much closer to zero. The presence of another woman aged 45-65 years in the household or an elderly female or male in the household significantly increases the likelihood of female participation by around 1 to 3 percentage points. This may reflect the ability of the woman to leave children at home with an adult. The magnitude of the impact of these potential childminders is much higher for women than men, for whom the effect is negligible. The presence of children in the household also has markedly different effects for men and women. For women, the presence of young children has a negative effect on the likelihood of participating. The presence of a child under two years of age decreases the probability of participation by 8 percentage points but has only a small (and positive) effect on men's labour market activity.

On the demand side of the labour market, we hypothesised that the coefficient for distance to the nearest district office would be negative as it was intended to capture distance to an active labour market. The coefficient, however, is positive, albeit small. The variable could be positively correlated with agricultural employment in rural areas and the positive coefficient reflecting women's greater involvement in agriculture. The villages' main sources of income variables show that female participation is highest in areas with agriculture and industry (which includes manufacturing). As the economy moves further away from agriculture to other sectors, however, female participation drops.

The results for Java-Bali and the outer islands follow a similar pattern to those presented in Table 10.4 and are presented in Table 10.A.1 in the appendix.

We re-estimate the model for each year of the SUSENAS separately to determine if the drivers of labour force participation have changed across time. The marginal effects for each year are presented in the appendix - see Table 10.A.2. This analysis shows that most of the drivers of FLFP (both the direction and magnitude of their impact) remain largely unchanged over time. These include if the individual is the household head or a widower and if they achieved at least primary level of education, the presence of elderly females and males in the household and the number of young children in the household. 
There are, however, several interesting changes in the drivers of FLFP over the period. In 1996, married women were around 23 percentage points less likely to participate than their single counterparts. By 2013, the negative impact of being married for women decreased to around 14 percentage points. The relationship between gender and industrial structure has also changed. Villages that have large trading or retail as their main source of income have become associated with higher levels of FLFP over time. In 1996, villages that had large trading or retail as their main income source had lower female participation than those whose main source of income came from agriculture by about 10 percentage points. But by 2013, the penalty for FLFP of such income sources had decreased to be only around 2 percentage points, suggesting women were starting to be accommodated in these industries.

\section{Age and cohort results}

The descriptive results showed that the raw FLFP figures have largely remained unchanged over the survey years. This section examines the results by age and cohort to enable us to understand the extent of changes in participation across the life cycle and/or the changing attitudes of younger cohorts towards participation that may keep the aggregate figures unchanged.

The results for males and females are shown in Figure 10.3. ${ }^{6}$ The results of the age analysis are largely as anticipated. Female labour force participation increases quickly up until around 25 years of age before slowing during the years typically associated with child bearing. It peaks at around 45 years of age before starting to decline. The contrast with males shows the extent of the disparity across these years. Men's participation rises sharply to almost 100 per cent once the period of educational attainment is over.

The analysis of age effects shows the extent to which women's decision to work is affected by their child-rearing responsibilities. Figure 10.4 compares the age analysis for Indonesia to a similar analysis conducted for the Netherlands (taken from Euwals et al. 2007). Notwithstanding the cultural and other country differences, the figure shows that there is a much larger decrease in women's labour force participation during the child-bearing years in Indonesia than in the Netherlands (once the

6 The sample averages of the explanatory variables are applied to the regression coefficients and added to the age and cohort effects to present the impact of different ages and cohorts on labour force participation. 
number of children and other explanatory variables are controlled for). There is no discernible drop associated with the child-bearing years in the Netherlands. Female labour force participation in the Netherlands reaches its peak of about 70 per cent at age 26. In contrast, in Indonesia, women's labour force participation at age 26 is about 15 percentage points below its peak (55 per cent compared to the 70 per cent it reaches at age 45 ).

The cohort effects plotted in Figure 10.3 reveal some interesting findings. They show that, other things being equal, FLFP has increased from around 40 per cent for those born in the 1940s to around 60 per cent for those born most recently in the 1980s and early 1990s. Male labour force participation has remained at about 95 per cent across the cohorts.
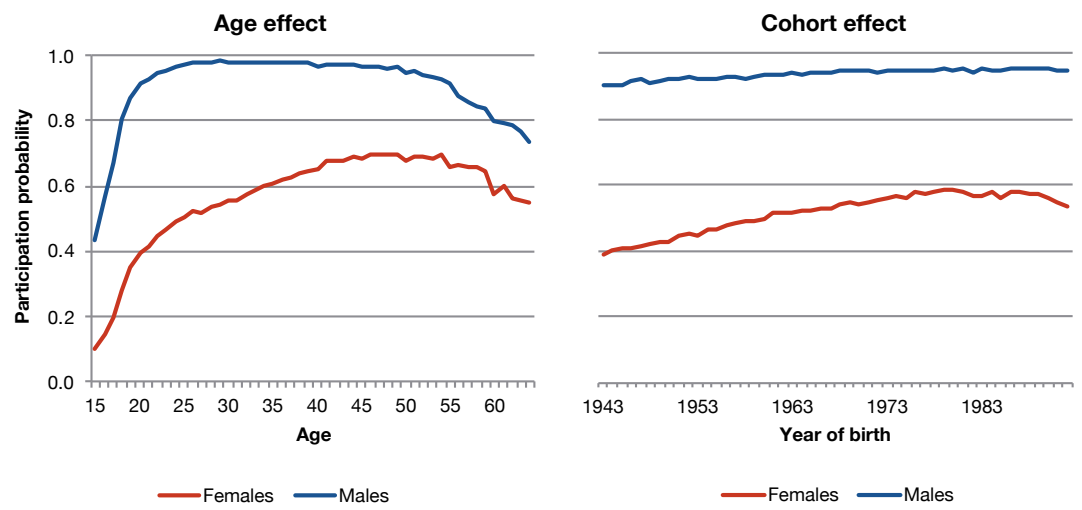

Figure 10.3. Age and cohort effects

Source. Authors' calculations using SUSENAS and PODES
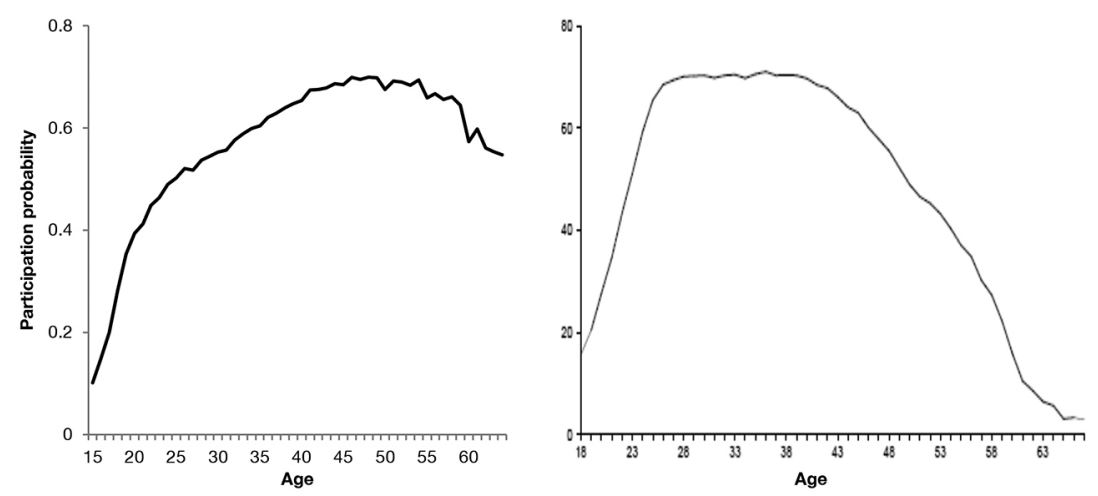

Figure 10.4. Age analysis of FLFP in Indonesia (left-hand side) and the Netherlands (right-hand side)

Source. Euwals et al. 2011 and authors' calculations using SUSENAS and PODES 
The cohort analysis thus reveals a large increase in the underlying propensity for women to participate in the labour force. This may reflect changing cultural norms. If this trend continues over time, as the older cohorts exit the labour market, we expect to eventually see an increase in FLFP. This increase seems to level off for the younger cohorts with no increases apparent after the 1973 cohort (aged 40 in 2013) but this may also reflect younger cohorts still completing their education.
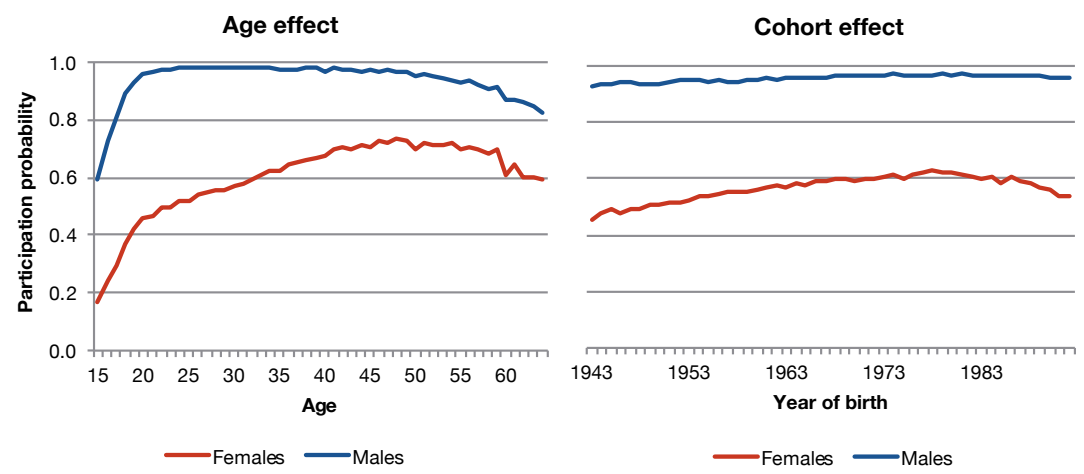

Figure 10.5. Age and cohort effects for rural areas

Source. Authors' calculations using SUSENAS and PODES
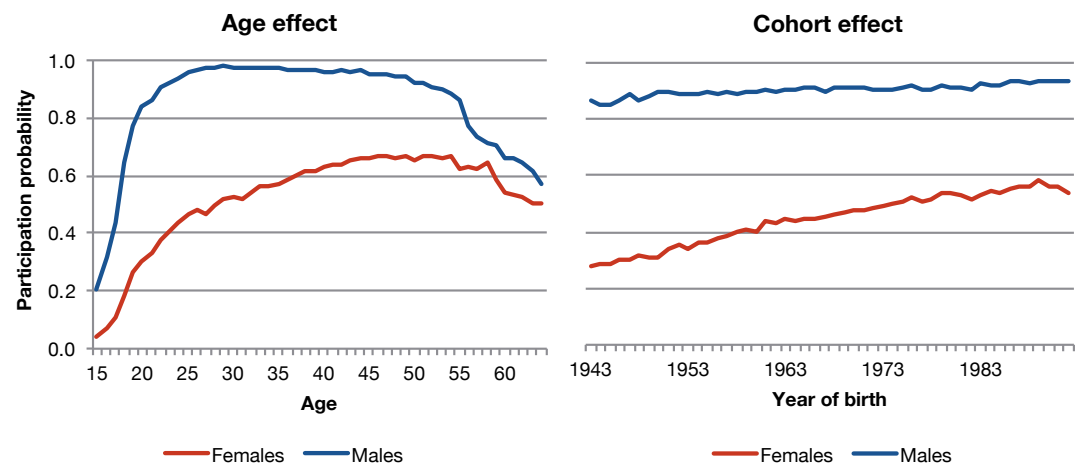

Figure 10.6. Age and cohort effects for urban areas

Source. Authors' calculations using SUSENAS and PODES

Figure 10.5 and Figure 10.6 present the results for rural and urban areas respectively. Some differences emerge. The age profile shows that the probability of participation in the labour market for younger urban females is lower than for their rural counterparts. This probably reflects the higher educational attainment in urban areas delaying their entry into the labour market. There is also a sharp decline in the male age profile 
at around 55 years of age. Unlike rural areas, where the decline in male labour force participation is gradual, in urban areas this is particularly pronounced. The current legislated retirement age in Indonesia is 55, and its effect is more evident in urban areas as a result of there being more formal sector jobs.

The cohort effects for women show greater differences between rural and urban areas. There have been larger increases in young women's labour force participation in urban areas than rural areas. The labour force participation of the older cohorts in urban areas is estimated at around 28 per cent and more than double to close to 60 per cent for the youngest cohorts. The increase in rural areas is much smaller but starts from a higher base (increasing from 45 per cent to 62 per cent). This is again consistent with changing cultural norms and women beginning to be accepted into non-agricultural employment in urban areas.

Figure 10.A.2 - Figure 10.A.5 in the appendix disaggregate the age and cohort effects further into their respective Java-Bali and the outer islands regions. The findings are largely consistent across the different regions.

The appendix further disaggregates the age and cohort effects for women by marital status, level of educational attainment and the number of children in various age categories in the household and the village's main source of income (see Figures 10.A.6 - 10.A.9). Figure 10.A.6 shows that labour force participation increased for both married and unmarried women in the younger cohorts. This suggests that the change in attitudes towards FLFP is not hindered by traditional roles related to marital status. ${ }^{7}$

Younger cohorts across all levels of educational attainment have increased their labour force participation compared to the older cohorts, except participation by upper-secondary educated women, which has remained constant (Figure 10.A.7). Figure 10.A.8 shows that FLFP increased for all women, regardless of the age of their children (although less for women with children under the age of two, and not much for birth cohorts since the late 1970s). Figure 10.A.9 shows that FLFP among the younger cohorts from villages with processing/industry, large trading/retail and services as their

7 The age effect also shows the considerable difference between married and unmarried females - for unmarried females, labour force participation reaches its peak by the age of 25, but for married females it takes until around 50 years of age for labour force participation to reach its peak. 
main source of income has increased relative to their older counterparts. ${ }^{8}$ Younger cohorts from agricultural villages have also increased their labour force participation but not to the same extent as the other sectors given that FLFP was already quite high in the older cohorts in agricultural villages. This has stalled, however, for cohorts born after 1970.

\section{Female labour force participation projections}

The G20 countries' 2014 commitment to decrease the female/male labour market participation gap by 25 per cent by 2025 means that Indonesia will need to increase its FLFP to 58.5 per cent. This goal will be challenging to achieve given that women's labour force participation in Indonesia has remained constant at just over 50 per cent for the last two decades. The analysis above, however, identified an increasing underlying propensity for women to participate in the labour market once other factors, such as changes in industrial structure, education and household composition, are controlled for. This section presents projections of FLFP to 2025.

We first examine how well the model predicts FLFP by comparing its predicted values with the observed levels in the raw data. We then estimate the rate of growth of each of the variables that determine FLFP in our model and use these to project FLFP through to 2025. We examine the sensitivity of our results to alternative scenarios and then conclude.

Using the estimated coefficients in equation (1), ${ }^{9}$ we calculate the predicted values of FLFP within the sample period and compare the result to the observed values. Figure 10.7 plots the actual and predicted values of FLFP. The model performs relatively well with the predicted value being close to the observed value, except in 2000 where the actual value dips from trend. The predicted trend between 1996 and 2007 is steeper that the trend after 2007.

8 Mining/quarrying also show improvement across the younger cohorts but the variability in these results and the age effect are likely due to the smaller sample size of females in this sector. For example, there are only 7,795 observations for this sector compared to 47,312 observations for the processing/ industry sector or 123,007 observations in the large trading/retail sector.

9 To calculate a national FLFP we estimate the model over both urban and rural samples, including a control for urban areas. Results are presented in Table 10.A.3 in the appendix. 


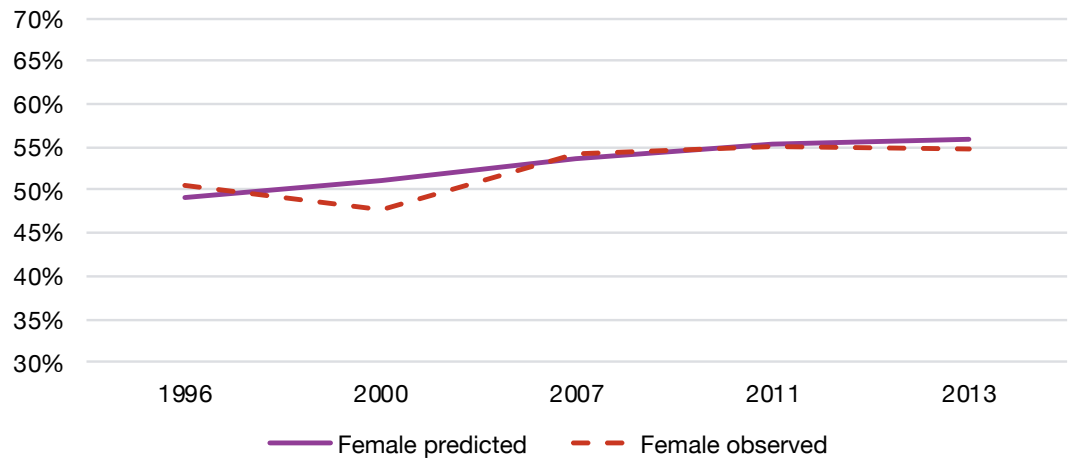

\section{Figure 10.7. Observed and predicted FLFP}

Source. Authors' calculations using SUSENAS

In order to predict the values of FLFP up to 2025, we need to make assumptions about the values of the variables that determine FLFP (e.g. level of education, industrial structure, age composition). We use a simple trend-time series model to predict the value of all the determinants up to 20 years ahead following equation (2), which we estimate using data from 1996 to 2013 .

$$
X_{i}=\alpha_{0}+\alpha_{1} t+\varepsilon_{i}
$$

where $t$ takes the value of 1 in 1996, 5 in 2000, 12 in 2007, 16 in 2011 and 18 in 2013; and $\varepsilon$ is the random error term. Table 10.5 shows the estimated percentage-point growth for each of the variables. In terms of education, this model predicts that the proportion of women with at least primary school education will decrease each year by 0.0043 percentage points while the proportion of women with tertiary education or more will increase by 0.0032 percentage points annually. The proportion of people living in urban areas is forecast to increase by 0.0073 percentage points each year.

Table 10.5. FLFP determinants' annual growth in percentage points

\begin{tabular}{|l|r|}
\hline Variables & Time trend \\
\hline Household head & 0.0020 \\
\hline Marital status: married & 0.0022 \\
\hline Marital status: divorced & 0.0000 \\
\hline Marital status: widowed & 0.0017 \\
\hline Education: primary & -0.0043 \\
\hline
\end{tabular}




\begin{tabular}{|l|r|}
\hline Variables & Time trend \\
\hline Education: lower secondary & 0.0040 \\
\hline Education: upper secondary & 0.0050 \\
\hline Education: tertiary & 0.0032 \\
\hline Household size & -0.0273 \\
\hline Number of elderly females & -0.0004 \\
\hline Number of elderly males & -0.0002 \\
\hline Presence of a potential babysitter & 0.0019 \\
\hline Number of children: 0-2 years & 0.0004 \\
\hline Number of children: 3-6 years & -0.0028 \\
\hline Number of children: 7-11 years & -0.0063 \\
\hline Number of children: 12-17 years & -0.0154 \\
\hline Urban & 0.0073 \\
\hline Distance to nearest district office ('100km) & 0.0063 \\
\hline Main income: mining/quarrying & 0.0004 \\
\hline Main income: processing/industry & 0.0007 \\
\hline Main income: large trading/retail & -0.0011 \\
\hline Main income: services other than trade & -0.0023 \\
\hline Unemployment ${ }^{\#}$ & -0.0014 \\
\hline
\end{tabular}

Notes. "Unemployment rate by region.

Source. Authors' calculations using SUSENAS and PODES

In order to apply the estimated life cycle effects (coefficients on age dummies) we also project the distribution of women across age groups. ${ }^{10}$ We assume that the proportion of people living in each province remains constant.

We present two projections. The most optimistic projection assumes that trends in underlying variables observed between 1996 and 2013 will continue. The second, more pessimistic projection, reflects the fact the growth in FLFP flattens off after 2007 (see Figure 10.7), and so uses only data from 2007 to 2013 to project into the future.

10 We compared our projected figures for the percentage of population by age group against UN forecasts. They are broadly similar, particularly for women aged over 40 years, who constitute the majority of working women. 


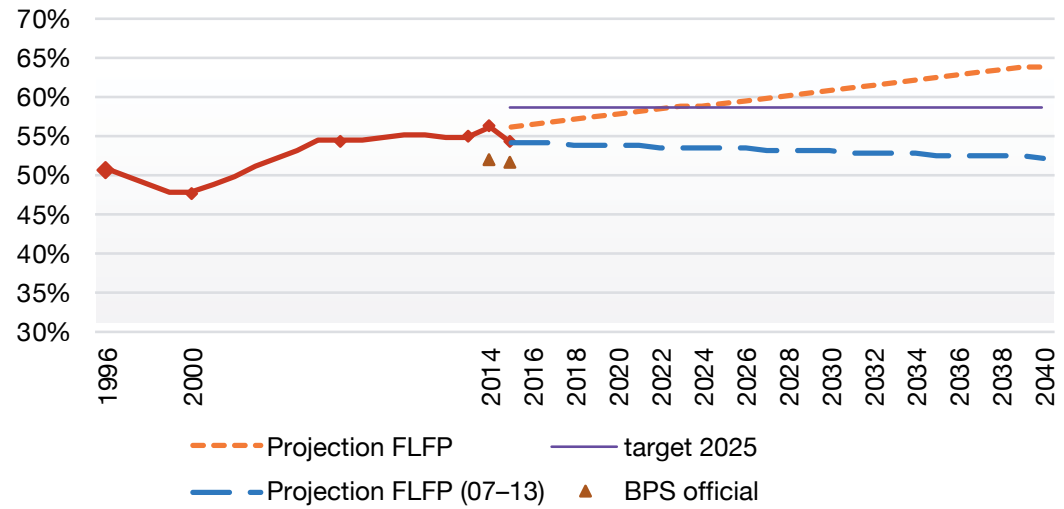

Figure 10.8. Projection of FLFP in Indonesia

Source. Authors' calculations using SUSENAS and BPS website

Figure 10.8 presents the results of both scenarios. The red line between 1996 and 2015 shows the observed levels. The brown triangles show the official Central Bureau of Statistics (BPS) estimated figures. The orange dotted line represents our estimated optimistic scenario and the blue dashed line represents the more pessimistic scenario. Under the optimistic scenario, FLFP just reaches the 58.5 per cent target by 2025 . It is forecast that FLFP will reach 59 per cent by 2025 . Under the less optimistic scenario, the FLFP will remain almost constant through to 2025 with FLFP decreasing slightly by $2025 .{ }^{11}$

\section{Summary and policy implications}

Female labour force participation in Indonesia has remained relatively constant from 1996 to 2013, even in the face of dramatic economic change. The analysis in this chapter, however, suggests that once individual, household and village characteristics are controlled for, there are signs that the underlying propensity for women to participate in the labour force has increased, particularly in urban areas. This is an interesting result and is consistent with societal attitudes changing to be more accepting of women participating in the labour market. Offsetting this secular increase in women's labour force participation are decreases in participation because

11 Note that both the predictions indicate an increase over the official BPS FLFP estimate for 2015. The BPS uses SAKERNAS information to calculate FLFP. 
of the lesser importance of agriculture. If the underlying propensity for women to participate continues to increase then, as the older cohorts exit the labour market, we expect FLFP to eventually increase.

We nevertheless find that the G20 target of 58.5 per cent FLFP by 2025 is unlikely to be reached. Our projections show that the target will only just be reached under our most optimistic scenario. The less optimistic (and arguably more realistic) scenario suggests that the FLFP may even decrease if the most recent trends continue.

The main drivers of FLFP (cohort and age effects aside) were found to be marital status, the number of children between 0 and 2 years of age in the household, educational attainment (particularly tertiary education) and the village industrial structure (with agriculture and manufacturing being female-oriented industries).

Our results have several policy implications. That marital status and the presence of young children has such a large negative impact on FLFP suggests that policies that support women to return to work after childbirth are likely to increase FLFP. These policies include the provision of some form of child-care for women with young children and policies and laws that encourage employers to make part-time and family-friendly work available. Increasing the educational attainment of women, particularly in rural areas where educational attainment remains low, is also likely to assist.

The cohort analysis finding that the underlying propensity for women to participate in the labour market is increasing is promising. The ongoing movement of the Indonesian economy away from the agricultural sector, however, given the importance of the agricultural sector to female employment, will continue to offset this effect. Thus, policies designed to provide women with access to employment in non-traditional industrial sectors, for example, through the provision of subsidised vocational education and/or campaigns that provide and promote opportunities for women in these sectors, are also worthy of attention.

\section{References}

Afridi, F, Dinkelman, T \& Mahajan, K (2016). Why are fewer married women joining the work force in India? A decomposition analysis over two decades, IZA Discussion Papers, 9722. 
Alisjahbana, AS \& Manning, C (2006). 'Labour market dimensions of poverty in Indonesia', Bulletin of Indonesian Economic Studies, 42(2), 235-61. doi.org/ $10.1080 / 00074910600873674$.

Andres, L, Dasgupta, B, Joseph, G, Abraham, V \& Correia, M (2017). Precarious drop: Reassessing patterns of female labor force participation in India, Policy Research Working Papers, World Bank Group, 8024.

Asian Development Bank (ADB) (2013). Gender equality in the labor market in the Philippines. Mandaluyong City, Philippines: Asian Development Bank.

_ (2015). Indonesia factsheet, 24 April. Mandaluyong City, Philippines: Asian Development Bank. www.adb.org/publications/indonesia-fact-sheet.

Asian Development Bank (ADB), International Labour Organization (ILO) \& Islamic Development Bank (IDB) (2010). Indonesia: Critical development constraints. Mandaluyong City, Philippines: Asian Development Bank.

Cepeda, L (2013). 'Gender wage inequality in Indonesia', 1 August, Poverty and Social Protection Cluster, World Bank Study.

Comola, M \& de Mello, L (2009). The determinants of employment and earnings in Indonesia: A multinomial selection approach, Economics Department Working Paper - OECD, No. 690.

Elias, S \& Noone, C (2011). 'The growth and development of the Indonesian economy', December, The Reserve Bank of Australia Bulletin.

Euwals R, Knoef, M \& van Vuuren D (2007). The trend in female labour force participation: What can be expected for the future?, IZA Discussion Paper Series, No. 3225.

Feridhanusetyawan, T \& Aswicahyono, H (2001). 'Gender assessment of the Indonesian labour market', East Asian Development Network, No. 9.

Gaddis, I \& Klasen, S (2014). 'Economic development, structural change, and women's labor force participation', Journal of Population Economics, 27(3), 639-81.

Gasparini, L, Marchionni, M, Badaracco, N \& Serrano, J (2015). Female labor force participation in Latin America: Evidence of deceleration. Documentos de Trabajo del CEDLAS.

Islam, I \& Chowdhury, A (2009). Growth, employment and poverty reduction in Indonesia. Geneva: International Labour Office (ILO).

Jayachandran, S (2015). 'The roots of gender inequality in developing countries', The Annual Review of Economics, 7, 63-88. 
Klasen, S \& Pieters, J (2015). 'What explains the stagnation of female labor force participation in urban India?', The World Bank Economic Review, 29(3), 449-78.

Manning, C (2000). 'Labour market adjustment to Indonesia's economic crisis: Context, trends and implications', Bulletin of Indonesian Economic Studies, 36(1), 105-36.

Schaner, S \& Das, S (2016). Female labor force participation in Asia: Indonesia country study, Asian Development Bank Economics Working Paper Series, No. 474. www.adb.org/sites/default/files/publication/180251/ewp-474.pdf.

Van Klaveren, M, Tijdens, K, Hughie-Williams, M \& Ramos Martin, N (2010). An overview of women's work and employment in Indonesia, AIAS Working Paper, Amsterdam.

\section{Appendix}

Table 10.A.1. Marginal effects by Java-Bali and the outer islands regions

\begin{tabular}{|c|c|c|c|c|}
\hline \multirow[t]{2}{*}{ Variables } & \multicolumn{2}{|c|}{ Java-Bali region } & \multicolumn{2}{|c|}{ Outer islands region } \\
\hline & Female & Male & Female & Male \\
\hline \multirow[t]{2}{*}{ Household head } & $0.1181^{\star \star \star}$ & $0.0370^{\star \star \star}$ & $0.2093^{\star \star \star}$ & $0.0485^{\star \star \star}$ \\
\hline & $(0.0040)$ & $(0.0019)$ & $(0.0032)$ & $(0.0014)$ \\
\hline \multicolumn{5}{|l|}{ Marital status: single (omitted) } \\
\hline \multirow[t]{2}{*}{ Marital status: married } & $-0.2316^{\star \star \star}$ & $0.1153^{\star \star \star}$ & $-0.1476^{\star \star \star}$ & $0.0983^{\star \star \star}$ \\
\hline & $(0.0029)$ & $(0.0023)$ & $(0.0024)$ & $(0.0017)$ \\
\hline \multirow[t]{2}{*}{ Marital status: divorced } & $-0.0467^{\star \star \star}$ & $0.0134^{\star \star \star}$ & $0.0126^{\star \star}$ & $0.0139^{\star \star \star}$ \\
\hline & $(0.0059)$ & $(0.0029)$ & $(0.0050)$ & $(0.0021)$ \\
\hline \multirow[t]{2}{*}{ Marital status: widowed } & $-0.2025^{\star \star \star}$ & $0.0286^{\star \star \star}$ & $-0.1586^{\star \star \star}$ & $0.0238^{\star \star \star}$ \\
\hline & $(0.0051)$ & $(0.0024)$ & $(0.0042)$ & $(0.0015)$ \\
\hline \multicolumn{5}{|c|}{ Education: no schooling (omitted) } \\
\hline \multirow[t]{2}{*}{ Education: primary } & $-0.0363^{\star \star \star}$ & $0.0156^{\star \star \star}$ & $-0.0437^{\star \star \star}$ & $-0.0015^{\star}$ \\
\hline & $(0.0022)$ & $(0.0013)$ & $(0.0018)$ & (0.0009) \\
\hline \multirow[t]{2}{*}{ Education: lower secondary } & $-0.1409^{\star \star \star}$ & $-0.0404^{\star * \star}$ & $-0.1018^{\star \star \star}$ & $-0.0548^{\star \star \star}$ \\
\hline & $(0.0026)$ & $(0.0015)$ & $(0.0018)$ & $(0.0010)$ \\
\hline \multirow[t]{2}{*}{ Education: upper secondary } & $-0.0734^{\star \star \star}$ & $0.0133^{\star \star \star}$ & $0.0521^{\star \star \star}$ & $-0.0215^{\star \star \star}$ \\
\hline & $(0.0027)$ & $(0.0016)$ & $(0.0030)$ & $(0.0016)$ \\
\hline \multirow[t]{2}{*}{ Education: tertiary } & $0.1811^{\star \star \star}$ & $0.0090^{\star \star \star}$ & $0.2893^{\star \star \star}$ & $-0.0122^{\star \star \star}$ \\
\hline & $(0.0037)$ & $(0.0019)$ & $(0.0025)$ & (0.0018) \\
\hline
\end{tabular}




\begin{tabular}{|c|c|c|c|c|}
\hline \multirow[t]{2}{*}{ Variables } & \multicolumn{2}{|c|}{ Java-Bali region } & \multicolumn{2}{|c|}{ Outer islands region } \\
\hline & Female & Male & Female & Male \\
\hline \multirow[t]{2}{*}{ Household size } & -0.0007 & $-0.0036^{\star \star \star}$ & $-0.0076^{\star \star \star}$ & $-0.0052^{\star \star \star}$ \\
\hline & $(0.0008)$ & $(0.0003)$ & $(0.0006)$ & $(0.0002)$ \\
\hline \multirow{2}{*}{$\begin{array}{l}\text { Number of women aged } 45-65 \\
\text { years }\end{array}$} & $0.0162^{\star \star \star}$ & -0.0009 & $0.0150^{\star \star \star}$ & $0.0030^{\star \star \star}$ \\
\hline & $(0.0023)$ & $(0.0009)$ & $(0.0019)$ & $(0.0006)$ \\
\hline \multirow[t]{2}{*}{ Number of elderly females } & $0.0177^{\star \star \star}$ & -0.0006 & $0.0228^{\star \star \star}$ & $0.0022^{\star \star}$ \\
\hline & $(0.0028)$ & $(0.0013)$ & $(0.0026)$ & $(0.0010)$ \\
\hline \multirow[t]{2}{*}{ Number of elderly males } & $0.0227^{\star \star \star}$ & $0.0073^{\star \star \star}$ & $0.0207^{\star \star \star}$ & $0.0096^{\star \star \star}$ \\
\hline & $(0.0029)$ & $(0.0015)$ & $(0.0025)$ & $(0.0011)$ \\
\hline \multirow[t]{2}{*}{ Number of children: $0-2$ years } & $-0.1121^{\star \star \star}$ & $0.0134^{\star \star \star}$ & $-0.0676^{\star \star \star}$ & $0.0130^{\star \star \star}$ \\
\hline & $(0.0021)$ & $(0.0012)$ & $(0.0015)$ & $(0.0007)$ \\
\hline \multirow[t]{2}{*}{ Number of children: 3-6 years } & $-0.0304^{\star \star \star}$ & $0.0132^{\star \star \star}$ & 0.0000 & $0.0102^{\star \star \star}$ \\
\hline & $(0.0018)$ & $(0.0010)$ & $(0.0013)$ & $(0.0006)$ \\
\hline \multirow[t]{2}{*}{ Number of children: $7-11$ years } & $-0.0028^{*}$ & $0.0111^{\star \star \star}$ & $0.0171^{\star \star \star}$ & $0.0108^{\star \star \star}$ \\
\hline & $(0.0015)$ & $(0.0008)$ & $(0.0011)$ & $(0.0005)$ \\
\hline \multirow[t]{2}{*}{ Number of children: $12-17$ years } & $0.0035^{\star \star}$ & $0.0088^{\star \star \star}$ & $0.0159^{\star \star \star}$ & $0.0083^{\star \star \star}$ \\
\hline & $(0.0014)$ & $(0.0007)$ & $(0.0010)$ & $(0.0004)$ \\
\hline \multirow[t]{2}{*}{ Distance to office ('100km) } & $0.0454^{\star \star \star}$ & $0.0192^{\star \star \star}$ & $0.0071^{\star \star \star}$ & $0.0023^{\star \star \star}$ \\
\hline & $(0.0052)$ & $(0.0027)$ & $(0.0008)$ & $(0.0003)$ \\
\hline \multicolumn{5}{|l|}{ Main income: agriculture (omitted) } \\
\hline \multirow[t]{2}{*}{ Main income: mining/quarrying } & $-0.0985^{\star \star \star}$ & $-0.0303^{\star \star \star}$ & $-0.1459^{\star \star *}$ & $-0.0188^{\text {*** }}$ \\
\hline & $(0.0181)$ & $(0.0118)$ & $(0.0063)$ & $(0.0035)$ \\
\hline \multirow[t]{2}{*}{ Main income: processing/industry } & $-0.0264^{\star \star \star}$ & $-0.0170^{\star \star \star}$ & $-0.0727^{\star \star \star}$ & $-0.0192^{\text {*** }}$ \\
\hline & $(0.0030)$ & $(0.0017)$ & $(0.0056)$ & $(0.0031)$ \\
\hline \multirow[t]{2}{*}{ Main income: large trading/retail } & $-0.0615^{\star \star \star}$ & $-0.0349^{\star \star \star}$ & $-0.1163^{\star \star \star}$ & $-0.0478^{\star \star \star}$ \\
\hline & $(0.0027)$ & $(0.0016)$ & $(0.0023)$ & $(0.0014)$ \\
\hline \multirow{2}{*}{$\begin{array}{l}\text { Main income: services other } \\
\text { than trade }\end{array}$} & $-0.0776^{\star \star \star}$ & $-0.0454^{\star \star \star}$ & $-0.1446^{\star \star \star}$ & $-0.0587^{\text {*** }}$ \\
\hline & $(0.0025)$ & $(0.0016)$ & $(0.0018)$ & $(0.0011)$ \\
\hline \multirow[t]{2}{*}{ Unemployment ${ }^{\#}$} & $-0.0212^{\star \star \star}$ & $-0.0026^{\star \star \star}$ & $-0.0102^{\star \star \star}$ & $0.0028^{\star * \star}$ \\
\hline & $(0.0008)$ & $(0.0004)$ & $(0.0006)$ & $(0.0002)$ \\
\hline Observations & 466,071 & 452,007 & 706,960 & 698,577 \\
\hline
\end{tabular}

Notes. Standard errors in parentheses, ${ }^{\star * \star} p<0.01,{ }^{\star \star} p<0.05,{ }^{\star} p<0.1$. Estimations include province, age and date of birth fixed effects. "Unemployment rate by region.

Source. Authors' calculations using SUSENAS and PODES 


\begin{tabular}{|c|c|c|c|c|c|c|c|c|c|c|c|c|c|c|c|c|c|}
\hline \multirow{2}{*}{ ำ } & $\frac{\frac{0}{\pi}}{\sum}$ & \begin{tabular}{l} 
t. \\
\multirow{2}{*}{} \\
0 \\
0 \\
0 \\
0 \\
0
\end{tabular} & $\begin{array}{l}\overparen{J} \\
\stackrel{8}{8} \\
\dot{0}\end{array}$ & & $\begin{array}{l}x \\
x \\
o \\
\stackrel{v}{*} \\
\stackrel{0}{0}\end{array}$ & $\begin{array}{l}\widehat{0} \\
\stackrel{0}{0} \\
\dot{0} \\
\dot{0}\end{array}$ & 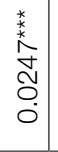 & $\begin{array}{l}\widetilde{\gamma} \\
8 \\
8 \\
\dot{0}\end{array}$ & 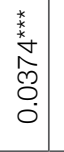 & $\begin{array}{l}\widehat{\infty} \\
\grave{0} \\
\dot{0} \\
\dot{0}\end{array}$ & & 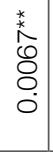 & 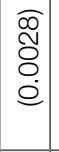 & 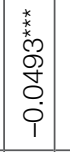 & 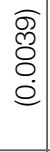 & $\begin{array}{l}\text { to } \\
\text { to } \\
0 \\
0 \\
0 \\
0 \\
0 \\
1\end{array}$ & $\begin{array}{l}0 \\
\text { ले } \\
8 \\
0\end{array}$ \\
\hline & 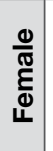 & 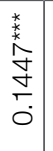 & $\begin{array}{l}\widehat{\widetilde{J}} \\
\stackrel{0}{0} \\
\stackrel{0}{0}\end{array}$ & & 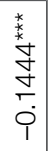 & $\begin{array}{l}\widehat{N} \\
\stackrel{0}{8} \\
\dot{0}\end{array}$ & $\begin{array}{l}0 \\
8 \\
8 \\
\dot{1} \\
\end{array}$ & $\begin{array}{l}\widetilde{\sigma} \\
\dot{\sigma} \\
\dot{0} \\
\dot{e}\end{array}$ & 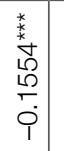 & 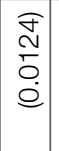 & & 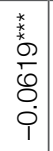 & 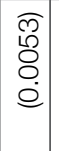 & 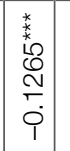 & $\begin{array}{l}\widehat{\overline{8}} \\
8 \\
\dot{0}\end{array}$ & \begin{tabular}{|l|}
$x$ \\
$x$ \\
0 \\
0 \\
00 \\
0 \\
0 \\
1 \\
\end{tabular} & $\begin{array}{l}0 \\
8 \\
8 \\
0\end{array}$ \\
\hline \multirow{2}{*}{$\bar{\delta}$} & $\frac{\frac{0}{\pi}}{\sum}$ & 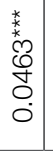 & 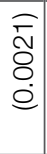 & & 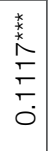 & 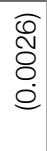 & 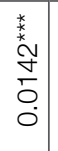 & 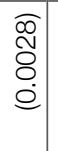 & 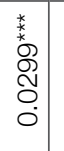 & $\begin{array}{l}\sigma \\
\bar{\delta} \\
\dot{0} \\
\dot{e}\end{array}$ & & $\begin{array}{l}\frac{0}{5} \\
\overline{8} \\
\circ \\
0\end{array}$ & 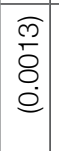 & 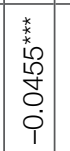 & 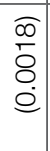 & 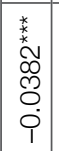 & 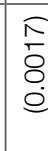 \\
\hline & 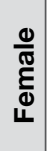 & $\begin{array}{l}\text { t. } \\
0 \\
0 \\
0 \\
0 \\
\vdots \\
0\end{array}$ & 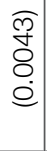 & & 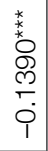 & $\begin{array}{l}\widetilde{10} \\
\tilde{0} \\
\varnothing \\
\dot{0}\end{array}$ & $\begin{array}{l}\tau \\
\frac{\sigma}{0} \\
\dot{0} \\
1\end{array}$ & $\begin{array}{l}0 \\
o \\
8 \\
\dot{0} \\
\dot{0}\end{array}$ & 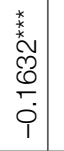 & \begin{tabular}{|l|} 
\\
8 \\
8 \\
$\dot{0}$ \\
$\dot{0}$
\end{tabular} & & $\begin{array}{l}x \\
6 \\
6 \\
\llcorner \\
0 \\
0 \\
i \\
1\end{array}$ & 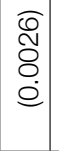 & 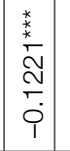 & 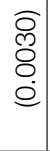 & \begin{tabular}{|c|}
$x$ \\
6 \\
0 \\
0 \\
0 \\
0 \\
0 \\
1
\end{tabular} & 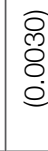 \\
\hline \multirow{2}{*}{ ఫ్ } & $\frac{\frac{\omega}{\pi}}{\sum}$ & 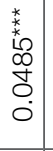 & $\begin{array}{l}\widehat{\bar{ஸ}} \\
8 \\
\dot{8} \\
\dot{0}\end{array}$ & & 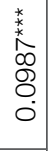 & $\begin{array}{l}\widehat{\mathscr{S}} \\
\stackrel{0}{0} \\
\dot{0} \\
\dot{0}\end{array}$ & 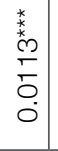 & $\begin{array}{l}\widehat{\bar{g}} \\
\delta \\
\dot{0} \\
\dot{0}\end{array}$ & 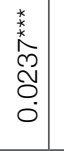 & $\begin{array}{l}\widetilde{\mathbb{N}} \\
\mathbb{O} \\
\stackrel{0}{0} \\
\dot{Q}\end{array}$ & & 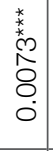 & $\begin{array}{l}\text { के } \\
\overline{8} \\
\dot{0} \\
\dot{0}\end{array}$ & $\begin{array}{l}* \\
* \\
6 \\
0 \\
\tilde{J} \\
0 \\
0 \\
1 \\
\end{array}$ & $\begin{array}{l}0 \\
\bar{\sigma} \\
\dot{0} \\
\dot{0}\end{array}$ & \begin{tabular}{|l|}
$*$ \\
$x$ \\
\multirow{2}{*}{} \\
2 \\
0 \\
0 \\
0 \\
0 \\
1 \\
\end{tabular} & $\begin{array}{l}0 \\
\overline{0} \\
0 \\
0\end{array}$ \\
\hline & 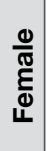 & 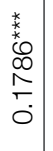 & $\begin{array}{l}0 \\
\dot{0} \\
8 \\
\dot{0}\end{array}$ & & 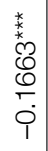 & $\begin{array}{l}\overparen{f} \\
\text { ஜి } \\
\dot{0} \\
\dot{0}\end{array}$ & 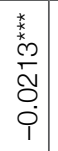 & $\begin{array}{l}\widetilde{I} \\
8 \\
\dot{8} \\
\dot{0}\end{array}$ & 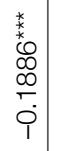 & \begin{tabular}{|l|} 
\\
8 \\
8 \\
$\dot{0}$ \\
$\dot{0}$
\end{tabular} & & 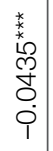 & $\begin{array}{l}\widetilde{\widehat{N}} \\
\tilde{\Upsilon} \\
\dot{8} \\
\dot{0}\end{array}$ & 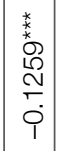 & $\begin{array}{l}\widehat{\widetilde{\rho}} \\
8 \\
\dot{0} \\
\dot{0}\end{array}$ & 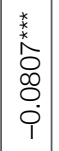 & $\begin{array}{l}\text { त } \\
\text { రి } \\
\dot{0} \\
\dot{0}\end{array}$ \\
\hline \multirow{2}{*}{ ষ্ণ } & $\frac{\frac{0}{\pi}}{\sum}$ & 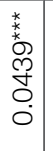 & $\begin{array}{l}\widetilde{\sim} \\
\grave{\delta} \\
\stackrel{0}{0} \\
\dot{0}\end{array}$ & & 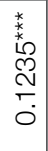 & 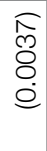 & 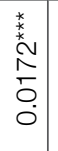 & $\begin{array}{l}0 \\
0 \\
\varnothing \\
0 \\
\dot{0}\end{array}$ & 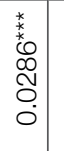 & $\begin{array}{l}\widehat{\widehat{N}} \\
\stackrel{1}{0} \\
\dot{0} \\
\dot{0} \\
\end{array}$ & & $\begin{array}{l}\text { Oి } \\
8 \\
0\end{array}$ & 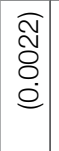 & \begin{tabular}{|l|} 
\\
$x$ \\
0 \\
8 \\
$o$ \\
0 \\
0 \\
1
\end{tabular} & \begin{tabular}{|l|}
$\widehat{\widetilde{g}}$ \\
$\tilde{\tilde{g}}$ \\
0 \\
$\dot{0}$ \\
\end{tabular} & \begin{tabular}{|l|}
$x$ \\
$x$ \\
0 \\
0 \\
0 \\
0 \\
0 \\
0 \\
\end{tabular} & $\begin{array}{l}\text { Оे } \\
\text { ஜे } \\
\stackrel{0}{0}\end{array}$ \\
\hline & 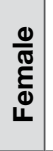 & $\begin{array}{l}\text { t. } \\
+ \\
8 \\
0 \\
0 \\
\vdots \\
0\end{array}$ & $\begin{array}{l}\widehat{8} \\
\varnothing \\
8 \\
\dot{0}\end{array}$ & & 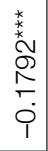 & 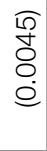 & $\begin{array}{l}\infty \\
8 \\
8 \\
0\end{array}$ & $\begin{array}{l}\text { ळ. } \\
\text { ठ } \\
\stackrel{0}{0}\end{array}$ & 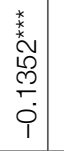 & \begin{tabular}{|l|}
$\widehat{0}$ \\
$\infty$ \\
0 \\
0 \\
$\dot{0}$
\end{tabular} & & $\begin{array}{l}\text { * } \\
60 \\
8 \\
0 \\
0 \\
9\end{array}$ & $\begin{array}{l}\text { 乃 } \\
\grave{D} \\
\dot{0} \\
\dot{e}\end{array}$ & $\begin{array}{l}* \\
6 \\
6 \\
0 \\
\vdots \\
\dot{\varphi}\end{array}$ & $\begin{array}{l}\sigma \\
\tilde{\Xi} \\
\delta \\
\dot{0}\end{array}$ & \begin{tabular}{|l|}
$*$ \\
$x$ \\
0 \\
0 \\
0 \\
0 \\
0 \\
$\dot{0}$ \\
\end{tabular} & 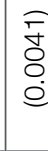 \\
\hline \multirow{2}{*}{ ஜ } & $\frac{\frac{0}{\pi}}{\sum}$ & $\begin{array}{l}\text { 类 } \\
\stackrel{0}{0} \\
\overline{8} \\
0 \\
0\end{array}$ & 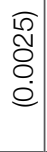 & & $\begin{array}{l}\text { t. } \\
\stackrel{6}{6} \\
5 \\
0 \\
0 \\
0\end{array}$ & 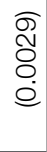 & $\begin{array}{l}0 \\
\stackrel{R}{0} \\
8 \\
0\end{array}$ & $\begin{array}{l}\overparen{N} \\
\tilde{D} \\
\dot{0} \\
\dot{0}\end{array}$ & $\begin{array}{l}\stackrel{+}{ } \\
\stackrel{8}{ } \\
\stackrel{0}{0}\end{array}$ & \begin{tabular}{|l|}
0 \\
0 \\
0 \\
0 \\
$\dot{0}$ \\
\end{tabular} & & $\begin{array}{l}0 \\
\overline{8} \\
0 \\
0 \\
1\end{array}$ & $\begin{array}{l}0 \\
0 \\
8 \\
\dot{0}\end{array}$ & \begin{tabular}{|l|} 
\\
$x$ \\
$k$ \\
0 \\
0 \\
0 \\
0 \\
1 \\
\end{tabular} & 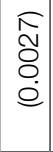 & 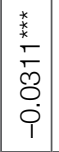 & $\begin{array}{l}\text { ल } \\
\text { ญे } \\
\stackrel{0}{0} \\
\stackrel{0}{0}\end{array}$ \\
\hline & 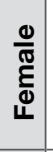 & 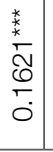 & 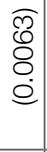 & & 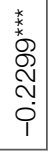 & $\begin{array}{l}\widehat{D} \\
\check{ల} \\
\dot{0} \\
\dot{0}\end{array}$ & $\begin{array}{l}\mathscr{8} \\
8 \\
8 \\
0\end{array}$ & $\begin{array}{l}0 \\
00 \\
0 \\
0 \\
0\end{array}$ & 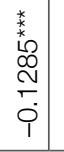 & 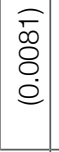 & & 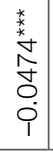 & 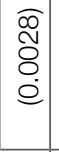 & 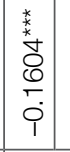 & 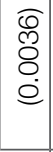 & 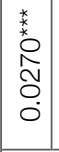 & $\begin{array}{l}\text { के } \\
\text { ठ } \\
\text { ¿ }\end{array}$ \\
\hline$\frac{20}{\frac{20}{5}}$ & & 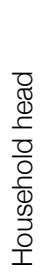 & & 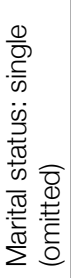 & 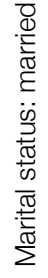 & & 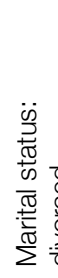 & & 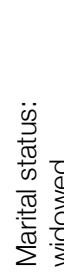 & $\begin{array}{l}\frac{0}{0} \\
\frac{1}{3} \\
\frac{0}{3} \\
\frac{0}{3}\end{array}$ & 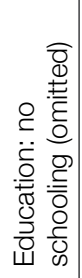 & 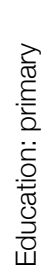 & & 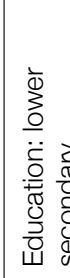 & & \multicolumn{2}{|c|}{ 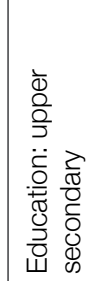 } \\
\hline
\end{tabular}




\begin{tabular}{|c|c|c|c|c|c|c|c|c|c|c|c|c|c|c|c|c|c|c|c|}
\hline \multirow{2}{*}{ ำ } & $\frac{0}{\frac{0}{\pi}}$ & 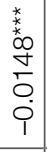 & $\begin{array}{l}0 \\
8 \\
8 \\
0\end{array}$ & \begin{tabular}{|l|}
$x$ \\
$x$ \\
0 \\
8 \\
8 \\
0 \\
0 \\
1 \\
\end{tabular} & 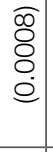 & $\begin{array}{l}1 \\
8 \\
8 \\
0 \\
0\end{array}$ & $\begin{array}{l}\widehat{\Omega} \\
\stackrel{\hat{Q}}{0} \\
\dot{0}\end{array}$ & $\begin{array}{l}+ \\
\dot{8} \\
\stackrel{0}{0}\end{array}$ & $\begin{array}{l}\overline{0} \\
\bar{\delta} \\
0 \\
0\end{array}$ & $\begin{array}{l}\text { t. } \\
6 \\
0 \\
\vdots \\
0 \\
0\end{array}$ & 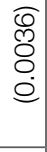 & \begin{tabular}{|l|} 
\\
$x$ \\
$k$ \\
0 \\
0 \\
0 \\
0 \\
0 \\
0
\end{tabular} & $\begin{array}{l}\widehat{Q} \\
\text { N } \\
8 \\
0 \\
0\end{array}$ & 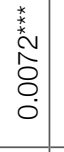 & $\begin{array}{c}\widehat{\bar{ஸ}} \\
8 \\
\dot{0}\end{array}$ & 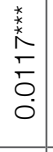 & $\begin{array}{l}\frac{\pi}{8} \\
8 \\
\dot{0}\end{array}$ & 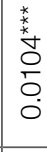 & $\begin{array}{l}10 \\
\frac{1}{8} \\
0 \\
0\end{array}$ \\
\hline & 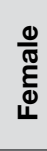 & 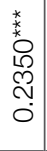 & 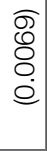 & \begin{tabular}{l} 
t. \\
\multirow{2}{*}{} \\
0 \\
0 \\
0 \\
0 \\
0 \\
1
\end{tabular} & 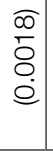 & 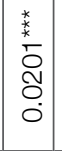 & $\begin{array}{l}\widetilde{\widehat{\theta}} \\
\stackrel{8}{8} \\
\dot{0} \\
\dot{0}\end{array}$ & 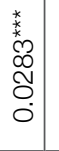 & 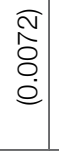 & $\begin{array}{l}\infty \\
5 \\
8 \\
\dot{0}\end{array}$ & $\begin{array}{l}0 \\
0 \\
8 \\
\dot{8} \\
0\end{array}$ & 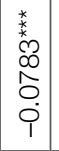 & $\begin{array}{l}\text { क् } \\
\text { ठ } \\
\text { ○. }\end{array}$ & $\begin{array}{l}* \\
0 \\
8 \\
8 \\
0 \\
1\end{array}$ & $\begin{array}{l}\widetilde{f} \\
\dot{\delta} \\
\dot{0} \\
\dot{0}\end{array}$ & $\begin{array}{l}\text { t. } \\
8 \\
0 \\
0 \\
0 \\
0\end{array}$ & 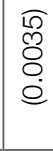 & 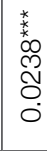 & \\
\hline \multirow[b]{2}{*}{$c$} & $\sum^{\frac{0}{\pi}}$ & 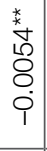 & 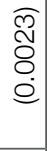 & 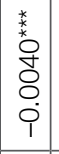 & $\begin{array}{l}\overparen{f} \\
8 \\
8 \\
\dot{0}\end{array}$ & \begin{tabular}{|l|}
$\infty$ \\
8 \\
8 \\
0 \\
0 \\
\end{tabular} & $\begin{array}{l}\text { बे } \\
8 \\
\dot{0}\end{array}$ & $\begin{array}{l}\frac{10}{0} \\
8 \\
0 \\
1\end{array}$ & $\begin{array}{l}10 \\
5 \\
8 \\
0 \\
\dot{0}\end{array}$ & \begin{tabular}{l} 
* \\
\multirow{2}{*}{} \\
$\stackrel{2}{8}$ \\
8 \\
0
\end{tabular} & $\begin{array}{l}\widehat{\Sigma} \\
\overline{8} \\
0 \\
\dot{0}\end{array}$ & \begin{tabular}{|l|}
$*$ \\
$*$ \\
$*$ \\
0 \\
8 \\
8 \\
8 \\
0 \\
0
\end{tabular} & $\begin{array}{l}\widehat{N} \\
\overline{8} \\
\dot{0} \\
\dot{0}\end{array}$ & $\begin{array}{l} \\
\text { to } \\
\stackrel{*}{8} \\
8 \\
8 \\
0 \\
0\end{array}$ & $\begin{array}{l}0 \\
0 \\
8 \\
0 \\
0\end{array}$ & 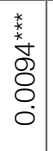 & $\begin{array}{l}\widehat{0} \\
8 \\
8 \\
0 \\
\varrho\end{array}$ & \begin{tabular}{l}
$*$ \\
\multirow{2}{*}{} \\
$\stackrel{*}{8}$ \\
0 \\
0
\end{tabular} & 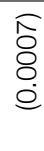 \\
\hline & 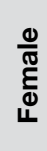 & 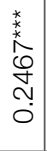 & 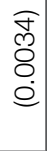 & \begin{tabular}{|l|}
$*$ \\
$*$ \\
$*$ \\
0 \\
8 \\
8 \\
0 \\
1
\end{tabular} & $\begin{array}{l}\overparen{8} \\
8 \\
8 \\
\dot{0}\end{array}$ & $\begin{array}{l}1 \\
\overline{8} \\
\dot{0}\end{array}$ & 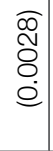 & 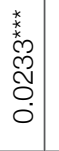 & 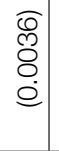 & 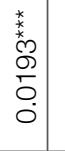 & 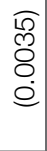 & \begin{tabular}{|l|}
$*$ \\
$k$ \\
0 \\
0 \\
0 \\
0 \\
0 \\
1 \\
1
\end{tabular} & $\begin{array}{l}\widehat{3} \\
\text { N } \\
\text { Oे } \\
\stackrel{0}{0}\end{array}$ & $\begin{array}{l}* \\
0 \\
8 \\
8 \\
8 \\
0 \\
1\end{array}$ & $\begin{array}{l}\text { क } \\
\overline{8} \\
\dot{0}\end{array}$ & 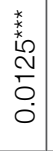 & $\begin{array}{l}\widehat{\widehat{0}} \\
\overline{8} \\
\stackrel{0}{0}\end{array}$ & 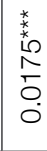 & 0 \\
\hline \multirow[t]{2}{*}{ 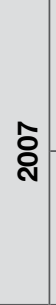 } & $\sum^{\frac{0}{\pi}}$ & 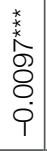 & 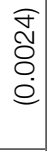 & \begin{tabular}{|l|}
$*$ \\
$x$ \\
0 \\
0 \\
0 \\
0 \\
0 \\
0 \\
1
\end{tabular} & $\begin{array}{l}\widetilde{0} \\
8 \\
0 \\
0\end{array}$ & \begin{tabular}{|l|}
8 \\
8 \\
8 \\
0 \\
1
\end{tabular} & 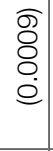 & $\begin{array}{l}0 \\
8 \\
8 \\
0\end{array}$ & $\begin{array}{l}\overparen{\nabla} \\
\overline{8} \\
\stackrel{0}{0}\end{array}$ & $\begin{array}{l}\text { t } \\
60 \\
00 \\
8 \\
8 \\
0\end{array}$ & 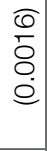 & 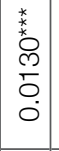 & $\begin{array}{l}\widehat{\sigma} \\
\overline{8} \\
0 \\
0\end{array}$ & $\begin{array}{l}* \\
* \\
0 \\
8 \\
8 \\
8 \\
0\end{array}$ & $\begin{array}{l}\text { ன } \\
8 \\
\check{0} \\
\dot{0}\end{array}$ & $\begin{array}{l}x \\
0 \\
0 \\
0 \\
8 \\
0 \\
0\end{array}$ & $\begin{array}{l}\text { 00 } \\
8 \\
8 \\
0\end{array}$ & 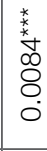 & $\begin{array}{l}\bar{Q} \\
8 \\
\circ \\
0\end{array}$ \\
\hline & $\begin{array}{l}\frac{\varrho}{\pi} \\
\text { है } \\
\stackrel{\Phi}{L}\end{array}$ & 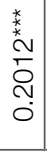 & $\begin{array}{l}0 \\
\dot{Q} \\
8 \\
\dot{0}\end{array}$ & 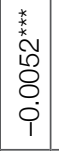 & 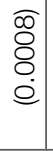 & 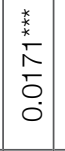 & 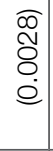 & 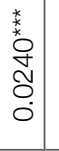 & $\begin{array}{l}0 \\
\tilde{8} \\
8 \\
0\end{array}$ & 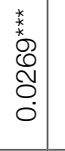 & $\begin{array}{l}0 \\
\tilde{0} \\
8 \\
0 \\
0\end{array}$ & \begin{tabular}{|l|}
$*$ \\
$x$ \\
6 \\
8 \\
0 \\
0 \\
0 \\
1
\end{tabular} & 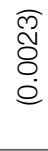 & \begin{tabular}{l} 
* \\
\multirow{x}{*}{} \\
80 \\
8 \\
0 \\
1
\end{tabular} & $\begin{array}{l}\text { क } \\
\overline{8} \\
\dot{0}\end{array}$ & $\begin{array}{l}\text { t } \\
6 \\
8 \\
8 \\
0 \\
0\end{array}$ & $\begin{array}{l}\widehat{\sigma} \\
\overline{8} \\
0 \\
0\end{array}$ & $\begin{array}{l}\stackrel{*}{x} \\
\stackrel{+}{\sigma} \\
0 \\
0\end{array}$ & $\begin{array}{l}10 \\
8 \\
8 \\
0 \\
0\end{array}$ \\
\hline \multirow[t]{2}{*}{8} & $\sum^{\frac{0}{\pi}}$ & $\begin{array}{l}\hat{m} \\
8 \\
0 \\
\dot{1}\end{array}$ & $\begin{array}{l}0 \\
8 \\
8 \\
0 \\
0\end{array}$ & \begin{tabular}{|l|}
$*$ \\
$x$ \\
6 \\
0 \\
0 \\
8 \\
0 \\
0 \\
1
\end{tabular} & $\begin{array}{l}\widehat{8} \\
8 \\
8 \\
0\end{array}$ & 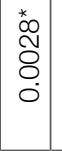 & $\begin{array}{l}0 \\
5 \\
8 \\
0 \\
0\end{array}$ & $\begin{array}{l}0 \\
8 \\
8 \\
0\end{array}$ & 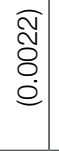 & \begin{tabular}{l}
$*$ \\
\multirow{2}{*}{} \\
8 \\
8 \\
8 \\
0
\end{tabular} & $\begin{array}{l}\overparen{\Im} \\
\stackrel{\mathbb{8}}{8} \\
\dot{0}\end{array}$ & $\begin{array}{l}\text { t. } \\
6 \\
6 \\
0 \\
0 \\
0 \\
0 \\
0\end{array}$ & $\begin{array}{l}\text { Oे } \\
\text { Oे } \\
\text { ¿ }\end{array}$ & 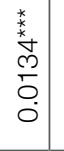 & $\begin{array}{l}0 \\
\vdots \\
8 \\
\dot{0}\end{array}$ & $\begin{array}{l}\frac{c}{6} \\
\frac{1}{6} \\
\frac{1}{0} \\
0 \\
0 \\
0\end{array}$ & $\begin{array}{l}\widehat{\mathrm{N}} \\
\overline{8} \\
0 \\
0\end{array}$ & \begin{tabular}{l} 
t. \\
\multirow{2}{*}{} \\
8 \\
0 \\
0 \\
0
\end{tabular} & 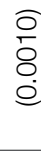 \\
\hline & 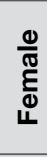 & 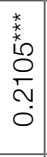 & $\begin{array}{l}0 \\
\infty \\
\circ \\
\dot{0} \\
\dot{0}\end{array}$ & 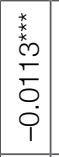 & $\begin{array}{l}0 \\
\overline{8} \\
8 \\
0 \\
0\end{array}$ & \begin{tabular}{|l|}
$*$ \\
0 \\
0 \\
0 \\
0 \\
0 \\
0 \\
\end{tabular} & 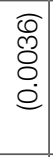 & 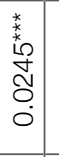 & 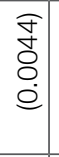 & 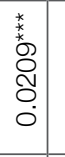 & 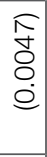 & \begin{tabular}{|l|}
$*$ \\
$x$ \\
0 \\
0 \\
0 \\
0 \\
0 \\
0 \\
\end{tabular} & 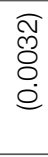 & $\begin{array}{l}* \\
1 \\
10 \\
8 \\
8 \\
0 \\
1\end{array}$ & 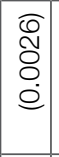 & 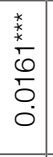 & 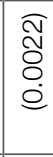 & \begin{tabular}{l} 
* \\
\multirow{2}{*}{} \\
0 \\
$\vdots$ \\
0 \\
0
\end{tabular} & 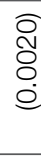 \\
\hline \multirow[t]{2}{*}{ ç } & $\sum^{\frac{0}{\pi}}$ & $\begin{array}{l}\frac{*}{*} \\
\frac{m}{2} \\
\vdots \\
\vdots \\
0\end{array}$ & 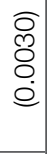 & 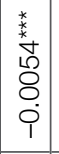 & $\begin{array}{l}\overparen{f} \\
8 \\
\stackrel{0}{0} \\
\dot{0}\end{array}$ & 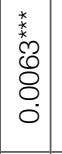 & 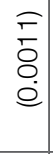 & $\begin{array}{l}5 \\
8 \\
0 \\
0\end{array}$ & 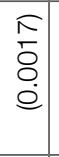 & $\begin{array}{l}* \\
6 \\
60 \\
80 \\
8 \\
0 \\
0\end{array}$ & $\begin{array}{l}0 \\
\overline{8} \\
0 \\
0\end{array}$ & 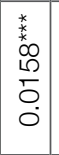 & $\begin{array}{l}\stackrel{\sigma}{\circ} \\
\dot{8} \\
\dot{0}\end{array}$ & 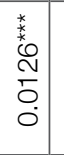 & $\begin{array}{l} \\
\\
8 \\
0 \\
\dot{0}\end{array}$ & 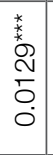 & $\begin{array}{l}\widehat{\sigma} \\
8 \\
\varnothing \\
\varrho\end{array}$ & 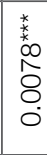 & $\begin{array}{l}8 \\
8 \\
0\end{array}$ \\
\hline & 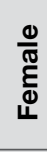 & 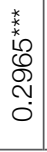 & $\begin{array}{l}\widehat{D} \\
0 \\
8 \\
0 \\
0\end{array}$ & 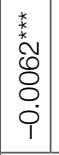 & $\begin{array}{l}0 \\
0 \\
8 \\
0 \\
0\end{array}$ & \begin{tabular}{|l|}
$*$ \\
6 \\
6 \\
0 \\
0 \\
0 \\
0 \\
\end{tabular} & $\begin{array}{l}\widetilde{\mathfrak{J}} \\
\stackrel{\tilde{\Xi}}{0} \\
\dot{0}\end{array}$ & $\begin{array}{l}\text { * } \\
\stackrel{*}{*} \\
\stackrel{1}{N} \\
\bigcirc \\
0 \\
0\end{array}$ & $\begin{array}{l}\widehat{\sigma} \\
\dot{8} \\
\dot{8} \\
\dot{0}\end{array}$ & 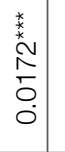 & 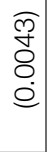 & \begin{tabular}{|l|}
$*$ \\
$*$ \\
6 \\
0 \\
0 \\
00 \\
0 \\
0 \\
0 \\
1
\end{tabular} & $\begin{array}{l}\widehat{\widehat{N}} \\
\stackrel{N}{8} \\
\dot{0} \\
\dot{0}\end{array}$ & 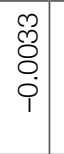 & 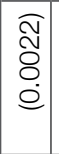 & 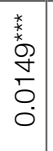 & 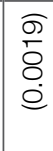 & 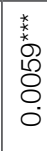 & $\begin{array}{l}\frac{1}{8} \\
\frac{8}{0} \\
\stackrel{0}{0}\end{array}$ \\
\hline \multicolumn{2}{|l|}{ 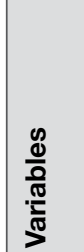 } & 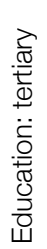 & & 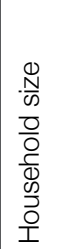 & \multicolumn{3}{|c|}{ 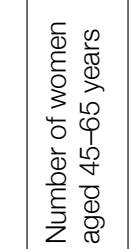 } & \multicolumn{2}{|c|}{ 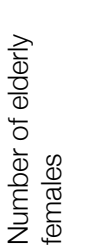 } & \multicolumn{2}{|c|}{ 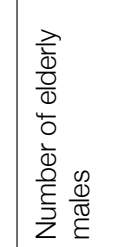 } & \multicolumn{2}{|c|}{ 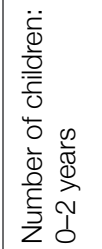 } & \multicolumn{2}{|c|}{ 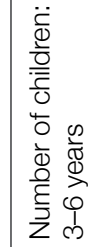 } & \multicolumn{2}{|c|}{ 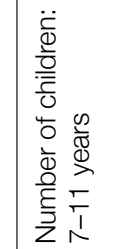 } & \multicolumn{2}{|c|}{ 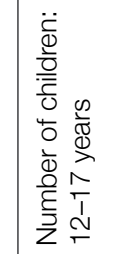 } \\
\hline
\end{tabular}




\begin{tabular}{|c|c|c|c|c|c|c|c|c|c|c|c|c|c|c|c|}
\hline \multirow{2}{*}{$\stackrel{m}{c}$} & & \begin{tabular}{l}
\multirow{2}{*}{} \\
๙े \\
8 \\
0 \\
0
\end{tabular} & $\begin{array}{l}0 \\
\overline{0} \\
8 \\
0 \\
0\end{array}$ & $\begin{array}{l}\frac{8}{+} \\
0 \\
0 \\
0\end{array}$ & $\begin{array}{l}\widehat{\sigma} \\
\hat{0} \\
0 \\
0\end{array}$ & $\begin{array}{l}1 \\
0 \\
8 \\
0 \\
0\end{array}$ & $\begin{array}{l}\widehat{\bar{\theta}} \\
\overline{8} \\
\dot{0}\end{array}$ & 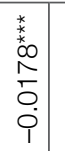 & $\begin{array}{l}\widehat{\widetilde{N}} \\
\stackrel{\varnothing}{0} \\
\dot{0} \\
\dot{0}\end{array}$ & $\begin{array}{l}\text { t } \\
\stackrel{2}{*} \\
\mathbb{N} \\
0 \\
0 \\
\dot{1}\end{array}$ & 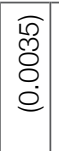 & 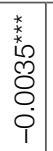 & $\begin{array}{l}\overline{0} \\
8 \\
8 \\
\dot{0}\end{array}$ & $\begin{array}{l}2 \\
\sigma \\
\tilde{D}^{\circ} \\
\infty\end{array}$ & \\
\hline & 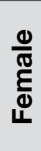 & 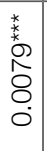 & 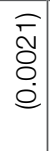 & 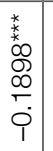 & $\begin{array}{l}\widehat{O} \\
\dot{b} \\
0 \\
\dot{0}\end{array}$ & $\begin{array}{l}\mathscr{0} \\
8 \\
8 \\
0 \\
1\end{array}$ & $\begin{array}{l}\widetilde{\tilde{m}} \\
\stackrel{\mathrm{N}}{0} \\
\stackrel{0}{0}\end{array}$ & 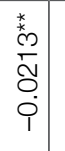 & $\begin{array}{l}\widehat{\sigma} \\
0 \\
\dot{0} \\
\dot{0}\end{array}$ & 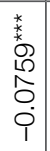 & \begin{tabular}{|c|}
$\overline{\bar{\theta}}$ \\
$\dot{0}$ \\
$\dot{0}$
\end{tabular} & 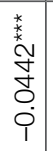 & 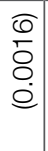 & $\begin{array}{l}\stackrel{o}{+} \\
0 \\
\hat{D}^{-}\end{array}$ & $\frac{\widehat{\sigma}}{\stackrel{0}{0}}$ \\
\hline & $\frac{0}{\frac{0}{\pi}}$ & 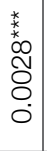 & 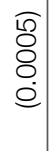 & 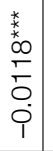 & $\begin{array}{l}\overparen{J} \\
\delta \\
\stackrel{0}{0} \\
\dot{0}\end{array}$ & 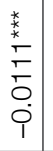 & 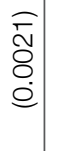 & $\begin{array}{l} \\
6 \\
6 \\
0 \\
\tilde{N} \\
0 \\
i \\
i\end{array}$ & $\begin{array}{l}0 \\
5 \\
\varnothing \\
0\end{array}$ & 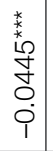 & $\begin{array}{l}0 \\
0 \\
0 \\
0 \\
0\end{array}$ & 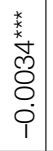 & $\begin{array}{l}\overparen{Ð} \\
8 \\
\stackrel{8}{0} \\
\dot{0}\end{array}$ & 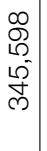 & \\
\hline & 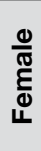 & 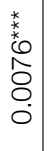 & $\begin{array}{l}0 \\
0 \\
8 \\
0 \\
0\end{array}$ & 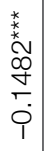 & $\begin{array}{l}\widetilde{0} \\
\varnothing \\
\varnothing \\
\dot{0}\end{array}$ & 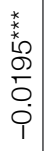 & 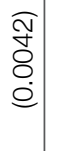 & 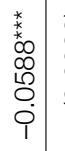 & $\begin{array}{l}\text { స్ } \\
\text { ঠి } \\
\stackrel{0}{0}\end{array}$ & 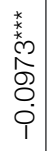 & 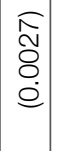 & 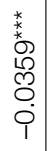 & 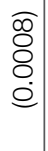 & 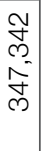 & \\
\hline & $\frac{0}{\frac{0}{\pi}}$ & $\begin{array}{l}x^{*} \\
\overbrace{}^{*} \\
\hat{D}^{2} \\
8 \\
0\end{array}$ & $\begin{array}{l}0 \\
8 \\
8 \\
0\end{array}$ & $\begin{array}{l}\frac{1}{8} \\
8 \\
9 \\
1\end{array}$ & $\begin{array}{l}\widetilde{\infty} \\
\dot{0} \\
\varnothing \\
\dot{0}\end{array}$ & 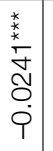 & 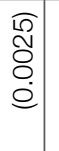 & 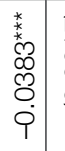 & $\begin{array}{l}\hat{x} \\
\overline{8} \\
0 \\
\dot{0}\end{array}$ & 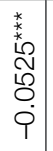 & 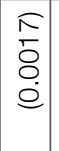 & 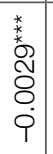 & $\begin{array}{l}\overline{\tilde{O}} \\
8 \\
0 \\
\dot{0}\end{array}$ & 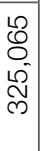 & \\
\hline & $\begin{array}{l}\frac{0}{\pi} \\
\text { है } \\
\text { है }\end{array}$ & 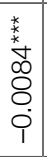 & \begin{tabular}{|l|}
\multirow{\sigma}{*}{} \\
$\overline{8}$ \\
$\dot{0}$ \\
\end{tabular} & 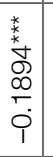 & $\begin{array}{l}\bar{\jmath} \\
0 \\
0 \\
0\end{array}$ & 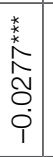 & $\begin{array}{l}0 \\
\dot{0} \\
8 \\
\dot{0}\end{array}$ & 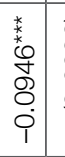 & 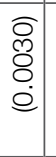 & 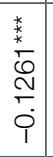 & 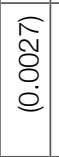 & 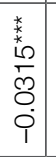 & $\begin{array}{l}1 \widehat{0} \\
8 \\
8 \\
\dot{0}\end{array}$ & 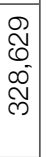 & \\
\hline & $\frac{0}{\frac{0}{\pi}}$ & 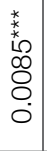 & $\begin{array}{l}\widehat{N} \\
\overline{8} \\
\dot{0} \\
0\end{array}$ & 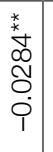 & $\begin{array}{l}\widetilde{N} \\
\tilde{N} \\
\dot{0} \\
\dot{0}\end{array}$ & 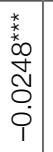 & $\begin{array}{l}\widetilde{\sigma} \\
\dot{\delta} \\
\dot{0}\end{array}$ & $\begin{array}{l} \\
x \\
t \\
6 \\
0 \\
0 \\
0 \\
\dot{1} \\
1\end{array}$ & $\begin{array}{l}\widehat{0} \\
\text { Nิ } \\
\stackrel{8}{0} \\
\dot{0}\end{array}$ & 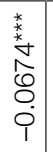 & 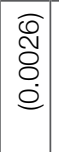 & 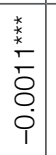 & $\begin{array}{l}\tilde{f} \\
8 \\
8 \\
\dot{0}\end{array}$ & 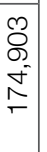 & \\
\hline & $\frac{0}{\pi}$ & 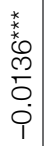 & 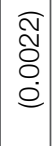 & 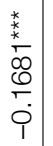 & $\begin{array}{l}\widehat{0} \\
0 \\
0 \\
0 \\
\dot{0}\end{array}$ & 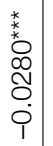 & 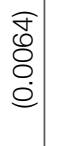 & 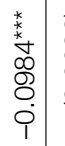 & $\begin{array}{l}\text { ब } \\
\text { ঠి } \\
\stackrel{.}{0} \\
\dot{e}\end{array}$ & 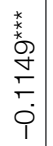 & 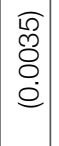 & 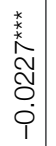 & $\begin{array}{l}\text { 尺ิ } \\
8 \\
\circ \\
\dot{0}\end{array}$ & $\begin{array}{l}0 \\
\mathbb{8} \\
\mathbb{8} \\
\Omega\end{array}$ & 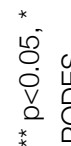 \\
\hline & $\frac{0}{\frac{0}{\pi}}$ & 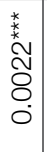 & $\begin{array}{l}0 \\
8 \\
8 \\
0 \\
0\end{array}$ & 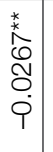 & $\begin{array}{l}\widetilde{0} \\
\stackrel{N}{0} \\
0 \\
\dot{0}\end{array}$ & 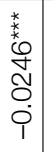 & 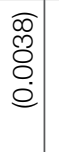 & $\begin{array}{l}* \\
x \\
0 \\
0 \\
0 \\
0 \\
0 \\
1\end{array}$ & 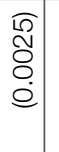 & \begin{tabular}{l|l}
$*$ \\
$x$ \\
0 \\
0 \\
8 \\
8 \\
0 \\
1
\end{tabular} & 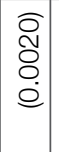 & 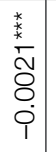 & $\begin{array}{l}\text { ส } \\
8 \\
8 \\
\dot{0}\end{array}$ & $\begin{array}{l}0 \\
\stackrel{0}{c} \\
\bar{N}\end{array}$ & \\
\hline & $\frac{0}{\frac{0}{2}}$ & \begin{tabular}{l}
$x^{*}$ \\
\multirow{2}{*}{} \\
$\delta$ \\
8 \\
0 \\
0
\end{tabular} & $\begin{array}{l}\widehat{N} \\
\overline{8} \\
0 \\
0\end{array}$ & \begin{tabular}{l} 
* \\
\multirow{*}{*}{} \\
0 \\
$N$ \\
$N$ \\
$i$ \\
$i$
\end{tabular} & $\begin{array}{l}\widehat{N} \\
\tilde{N} \\
\dot{0} \\
0\end{array}$ & 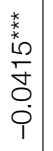 & 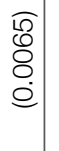 & $\begin{array}{l}* \\
* \\
0 \\
\infty \\
8 \\
0 \\
0 \\
1\end{array}$ & 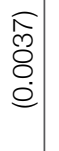 & 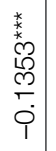 & \begin{tabular}{|c|}
$\widehat{\bar{m}}$ \\
$\dot{\delta}$ \\
$\dot{e}$
\end{tabular} & \begin{tabular}{l} 
* \\
\multirow{*}{*}{} \\
0 \\
0 \\
0 \\
0 \\
1
\end{tabular} & $\begin{array}{l}0 \\
8 \\
8 \\
\dot{0}\end{array}$ & $\begin{array}{l}م \\
\infty \\
n \\
0 \\
N \\
N\end{array}$ & 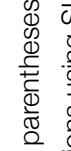 \\
\hline & \multicolumn{2}{|c|}{ 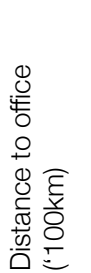 } & \multicolumn{2}{|c|}{ 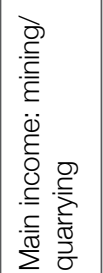 } & \multicolumn{2}{|c|}{ 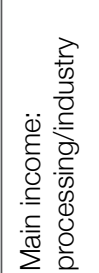 } & \multicolumn{2}{|c|}{ 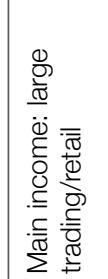 } & \multicolumn{2}{|c|}{ 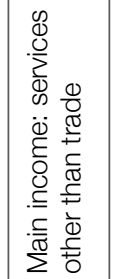 } & \multicolumn{2}{|l|}{ 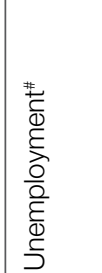 } & 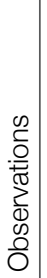 & $\ddot{\oplus}$ \\
\hline
\end{tabular}


Table 10.A.3. Probit estimation of FLFP for use in the projections

\begin{tabular}{|c|c|c|}
\hline & $\begin{array}{c}\text { All years } \\
(1996-2013)\end{array}$ & $\begin{array}{c}\text { Since } 2007 \\
(2007,2011,2013)\end{array}$ \\
\hline \multirow[t]{2}{*}{ Household head } & $0.4517^{\star \star \star}$ & $0.4703^{\star \star \star}$ \\
\hline & $(0.0070)$ & $(0.0117)$ \\
\hline \multicolumn{3}{|l|}{ Marital status: single (omitted) } \\
\hline \multirow[t]{2}{*}{ Marital status: married } & $-0.4557^{\star \star \star}$ & $-0.4388^{\star \star \star}$ \\
\hline & $(0.0049)$ & $(0.0083)$ \\
\hline \multirow[t]{2}{*}{ Marital status: divorced } & -0.0079 & $-0.0404^{\star \star}$ \\
\hline & $(0.0095)$ & $(0.0161)$ \\
\hline \multirow[t]{2}{*}{ Marital status: widowed } & $-0.4245^{\star \star \star}$ & $-0.4762^{\star \star \star}$ \\
\hline & $(0.0087)$ & $(0.0143)$ \\
\hline \multicolumn{3}{|l|}{ Education: no schooling (omitted) } \\
\hline \multirow[t]{2}{*}{ Education: primary } & $-0.1069^{\star \star \star}$ & $-0.1049^{\star \star *}$ \\
\hline & $(0.0034)$ & $(0.0061)$ \\
\hline \multirow[t]{2}{*}{ Education: lower secondary } & $-0.3067^{\star \star \star}$ & $-0.2832^{\star \star \star *}$ \\
\hline & $(0.0042)$ & $(0.0071)$ \\
\hline \multirow[t]{2}{*}{ Education: upper secondary } & $-0.0868^{\star \star \star}$ & $-0.1478^{\star \star \star}$ \\
\hline & $(0.0043)$ & $(0.0073)$ \\
\hline \multirow[t]{2}{*}{ Education: tertiary } & $0.7147^{\star \star \star}$ & $0.6466^{\star \star \star}$ \\
\hline & $(0.0068)$ & $(0.0107)$ \\
\hline \multirow[t]{2}{*}{ Household size } & $-0.0122^{\star \star *}$ & $-0.0071^{\star \star \star ~}$ \\
\hline & $(0.0011)$ & $(0.0019)$ \\
\hline \multirow[t]{2}{*}{ Number of women aged $45-65$ years } & $0.0513^{\star \star \star}$ & $0.0456^{\star \star \star}$ \\
\hline & $(0.0048)$ & $(0.0081)$ \\
\hline \multirow[t]{2}{*}{ Number of elderly females } & $0.0522^{\star \star \star}$ & $0.0491^{\star \star \star}$ \\
\hline & $(0.0048)$ & $(0.0080)$ \\
\hline \multirow[t]{2}{*}{ Number of elderly males } & $0.0373^{\star \star \star}$ & $0.0210^{\star \star \star}$ \\
\hline & $(0.0037)$ & $(0.0063)$ \\
\hline \multirow[t]{2}{*}{ Number of children: $0-2$ years } & $-0.2065^{\star \star \star}$ & $-0.1992^{\star \star \star}$ \\
\hline & $(0.0031)$ & $(0.0053)$ \\
\hline \multirow[t]{2}{*}{ Number of children: 3-6 years } & $-0.0221^{\star \star \star}$ & $-0.0319^{\star \star \star}$ \\
\hline & $(0.0026)$ & $(0.0045)$ \\
\hline \multirow[t]{2}{*}{ Number of children: $7-11$ years } & $0.0283^{\star \star \star}$ & $0.0163^{\star \star \star}$ \\
\hline & $(0.0022)$ & $(0.0039)$ \\
\hline
\end{tabular}


ACHIEVING INCLUSIVE GROWTH IN THE ASIA PACIFIC

\begin{tabular}{|c|c|c|}
\hline & $\begin{array}{c}\text { All years } \\
(1996-2013)\end{array}$ & $\begin{array}{c}\text { Since } 2007 \\
(2007,2011,2013)\end{array}$ \\
\hline \multirow[t]{2}{*}{ Number of children: $12-17$ years } & $0.0316^{\star \star \star}$ & $0.0297^{\star \star \star}$ \\
\hline & $(0.0021)$ & $(0.0036)$ \\
\hline \multirow[t]{2}{*}{ Urban } & $-0.2403^{\star \star \star}$ & $-0.2589^{\star \star \star}$ \\
\hline & $(0.0036)$ & $(0.0060)$ \\
\hline \multirow[t]{2}{*}{ Distance to office ('100 km) } & $0.0152^{\star \star \star}$ & $0.0129^{\star \star \star}$ \\
\hline & $(0.0020)$ & $(0.0036)$ \\
\hline \multicolumn{3}{|l|}{ Main income: agriculture (omitted) } \\
\hline \multirow[t]{2}{*}{ Main income: mining/quarrying } & $-0.2425^{\star \star \star}$ & $-0.2722^{\star * *}$ \\
\hline & $(0.0157)$ & $(0.0288)$ \\
\hline \multirow[t]{2}{*}{ Main income: processing/industry } & $0.0160^{\star *}$ & $0.0237^{\star \star}$ \\
\hline & $(0.0068)$ & $(0.0116)$ \\
\hline \multirow[t]{2}{*}{ Main income: large trading/retail } & $-0.0819^{\star \star \star}$ & $-0.0815^{\star \star \star}$ \\
\hline & $(0.0050)$ & $(0.0084)$ \\
\hline \multirow[t]{2}{*}{ Main income: services other than trade } & $-0.1491^{\star \star *}$ & $-0.1447^{\star \star \star}$ \\
\hline & $(0.0045)$ & $(0.0076)$ \\
\hline \multirow[t]{2}{*}{ Unemployment ${ }^{*}$} & $-0.0141^{\star \star \star}$ & $-0.0146^{\star \star}$ \\
\hline & $(0.0017)$ & $(0.0070)$ \\
\hline \multirow[t]{2}{*}{ Constant } & $-0.4532^{\star \star \star}$ & $-0.4119^{\star \star \star}$ \\
\hline & $(0.0249)$ & $(0.0413)$ \\
\hline Observations & $1,173,031$ & 415,669 \\
\hline
\end{tabular}

Notes. Standard errors in parentheses, ${ }^{* \star} p<0.01,{ }^{* *} p<0.05,{ }^{*} p<0.1$. Estimations include province, age and date of birth fixed effects. "Unemployment rate by region.

Source. Authors' calculations using SUSENAS and PODES 


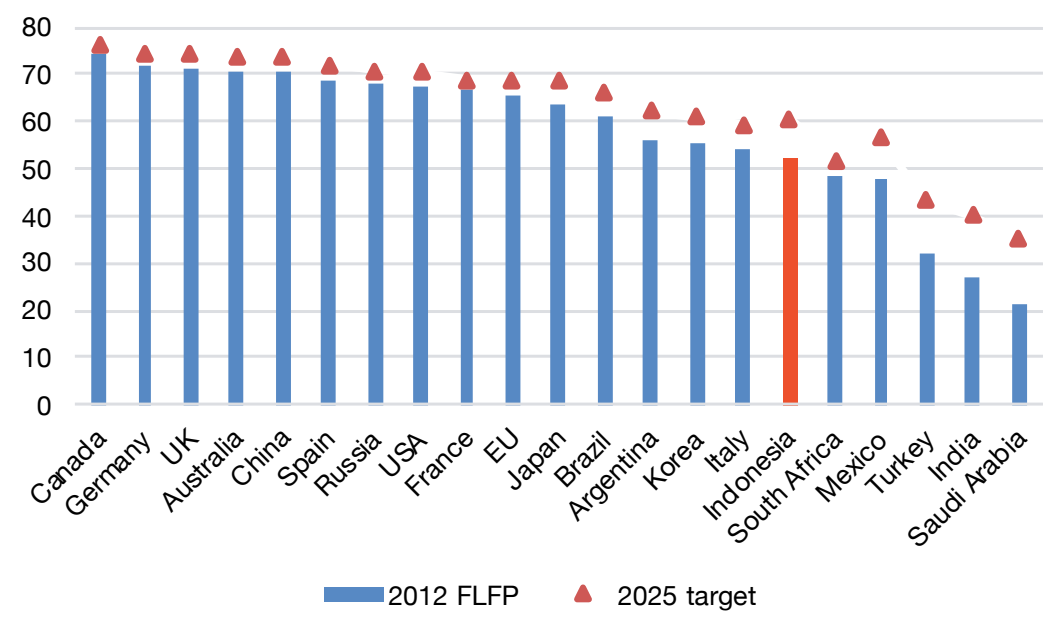

\section{Figure 10.A.1. G20 FLFP targets}

Source. ILO (2014) Achieving stronger growth by promoting a more gender-balanced economy. Report prepared for G20 Labour and Employment Ministerial Meeting, 10-11 September 2014. www.oecd.org/g20/topics/employment-and-social-policy/ILO-IMFOECD-WBG-Achieving-stronger-growth-by-promoting-a-more-gender-balancedeconomy-G20.pdf

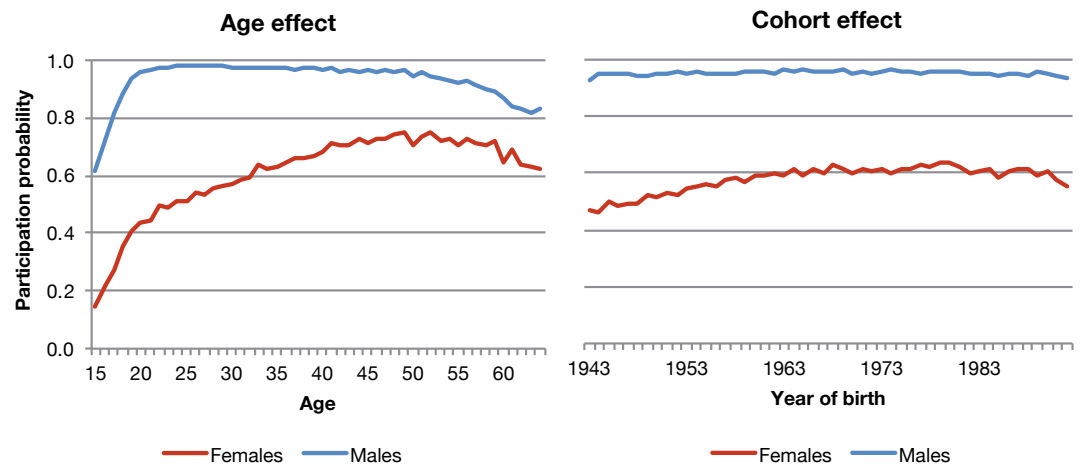

Figure 10.A.2. Age and cohort effects for rural Java-Bali region

Source. Authors' calculations using SUSENAS and PODES 

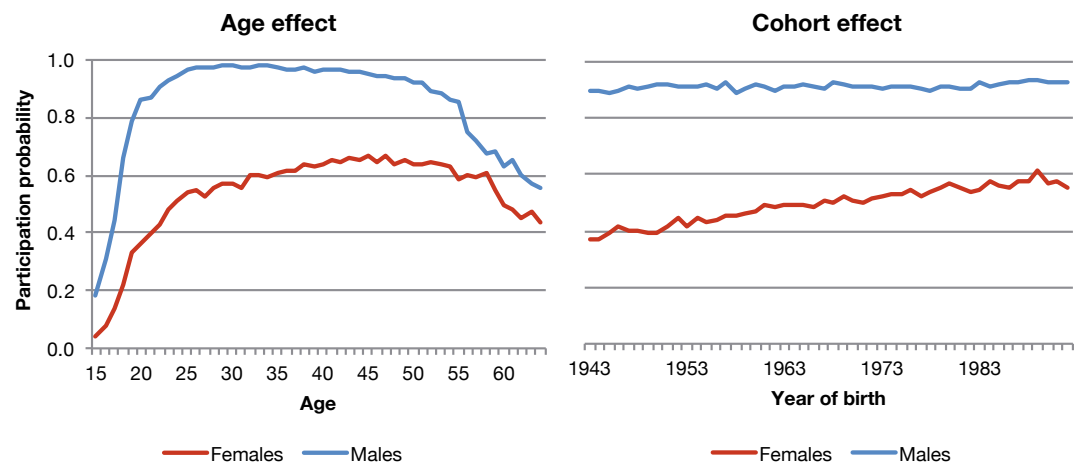

Figure 10.A.3. Age and cohort effects for urban Java-Bali region

Source. Author's calculations using SUSENAS and PODES
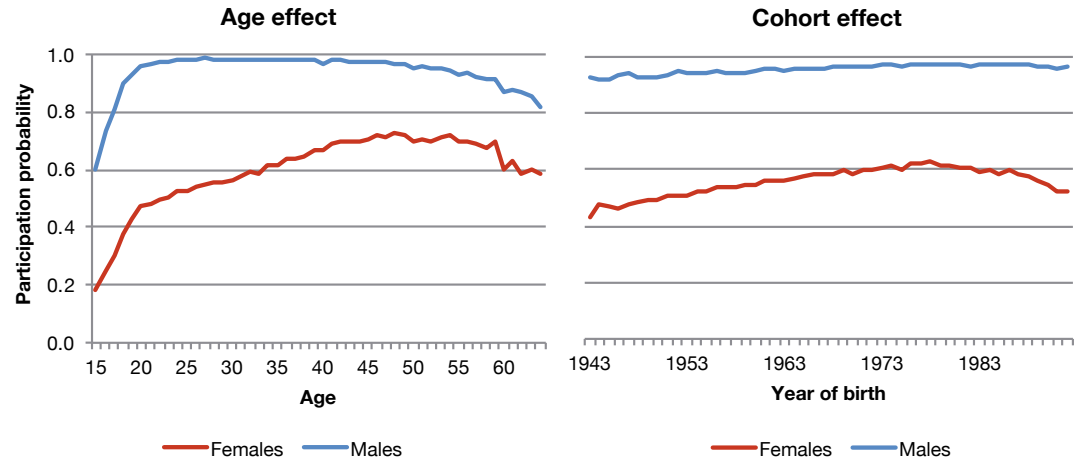

Figure 10.A.4. Age and cohort effects for rural outer islands region

Source. Authors' calculations using SUSENAS and PODES
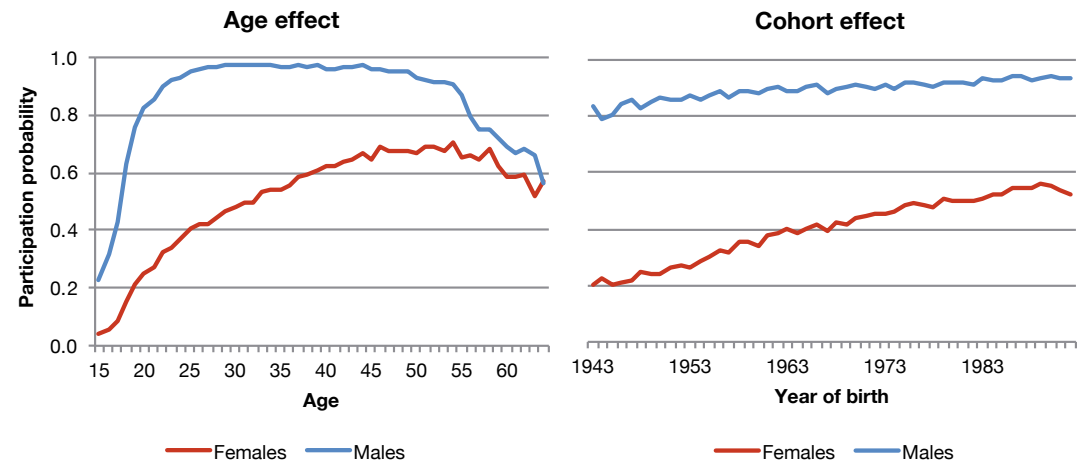

Figure 10.A.5. Age and cohort effects for urban outer islands region

Source. Authors' calculations using SUSENAS and PODES 

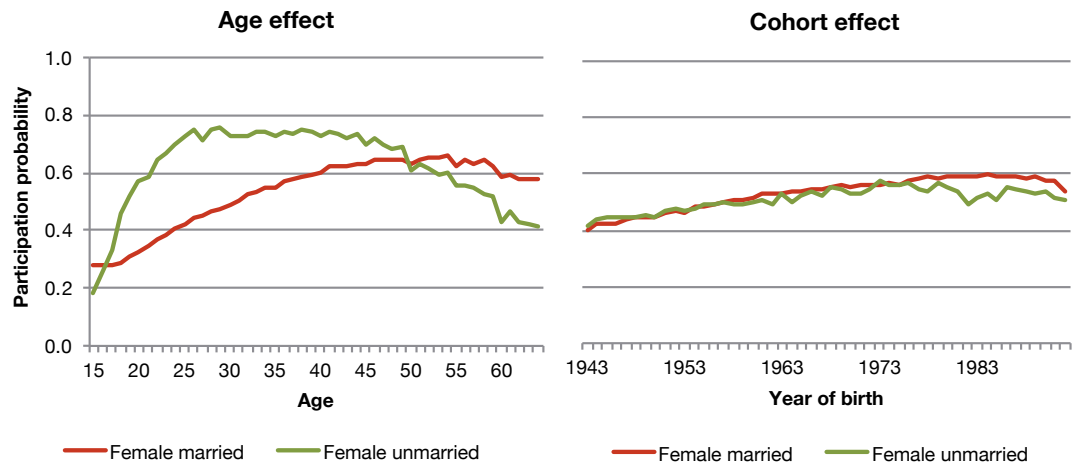

Figure 10.A.6. Age and cohort effects by marital status

Note. Unmarried includes single, divorced and widowed.

Source. Authors' calculations using SUSENAS and PODES
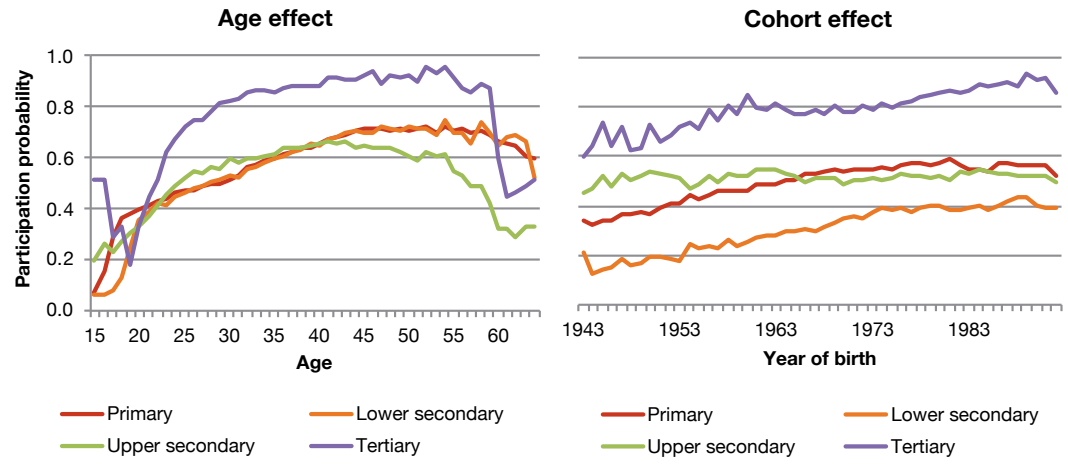

Figure 10.A.7. Age and cohort effects for females by educational attainment

Source. Authors' calculations using SUSENAS and PODES 

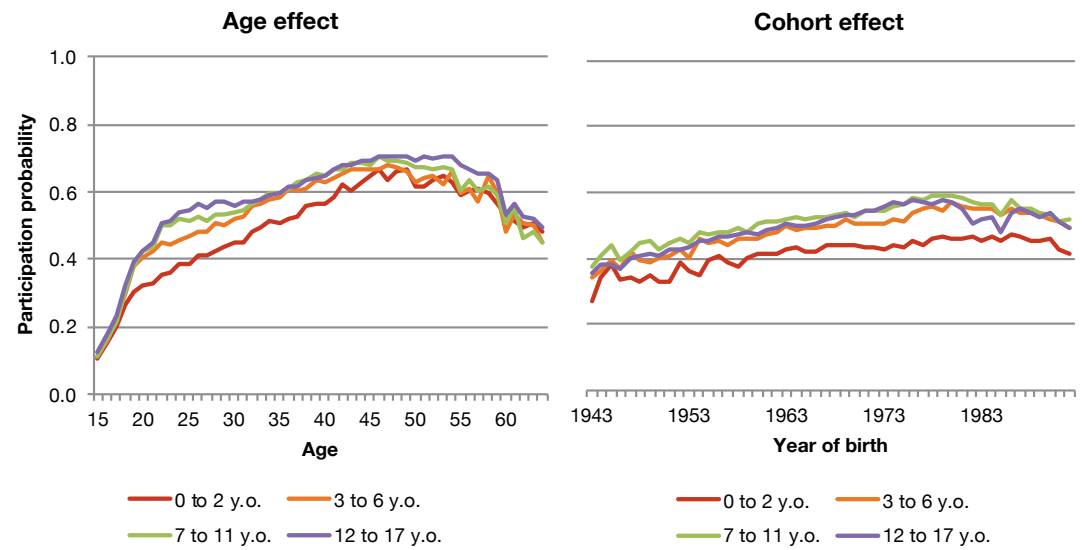

Figure 10.A.8. Age and cohort effects for females by number of children Source. Authors' calculations using SUSENAS and PODES
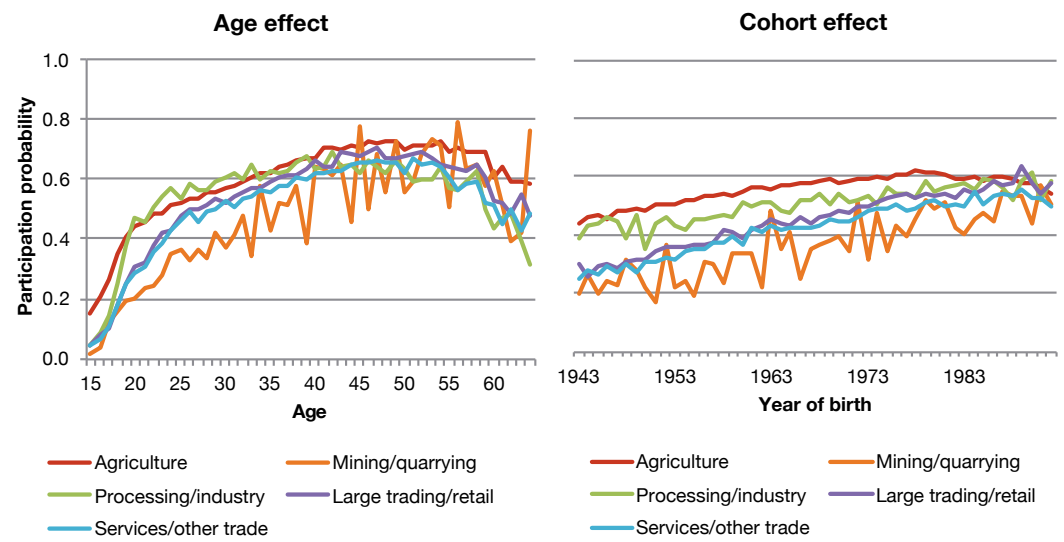

Figure 10.A.9. Age and cohort effects for females by village main income type

Source. Authors' calculations using SUSENAS and PODES 
This text is taken from Achieving Inclusive Growth in the Asia Pacific, edited by Adam Triggs and Shujiro Urata, published 2020 by ANU Press, The Australian National University, Canberra, Australia.

doi.org/10.22459/AIGAP.2020.10 